\title{
Obama chez moi! The invasion of metropolitan France by the land planarian Obama nungara (Platyhelminthes, Geoplanidae)
}

\author{
Jean-Lou Justine ${ }^{\text {Corresp., } 1}$, Leigh Winsor ${ }^{2}$, Delphine Gey ${ }^{3}$, Pierre Gros $^{4}$, Jessica Thévenot ${ }^{5}$ \\ ${ }^{1}$ ISYEB, Institut de Systématique Évolution Biodiversité, UMR7205 CNRS, EPHE, MNHN, UPMC, Université des Antilles, Muséum National d'Histoire \\ Naturelle, Paris, France \\ ${ }^{2}$ College of Science and Engineering, James Cook University, Townsville, Queensland, Australia \\ ${ }^{3}$ Service de Systématique Moléculaire, Museum national d'Histoire naturelle, Paris, France \\ 4 Amateur Naturalist, Cagnes-sur-Mer, France \\ 5 UMS Patrinat (CNRS - AFB - MNHN), Muséum National d'Histoire Naturelle, Paris, France \\ Corresponding Author: Jean-Lou Justine \\ Email address: justine@mnhn.fr
}

Background Obama nungara is a species of land flatworm originating from South America; the species was recently described and distinguished from a similar species, Obama marmorata. Obama nungara has invaded several countries of Europe, but the extent of the invasion has not been thoroughly mapped. Methods In this paper, based on a five and a half-year survey undertaken by citizen science, which yielded 530 records from 2013 to 2018, we analysed information about the invasion of Metropolitan France by 0 . nungara. We also investigated the variability of newly obtained cytochrome c oxidase 1 (COI) sequences of specimens from France, Italy and Switzerland. Results Obama nungara was recorded from 72 of the 96 Departments of Metropolitan France. The species is especially abundant along the Atlantic coast, from the Spanish border to Brittany, and along the Mediterranean coast, from the Spanish border to the Italian border. More than half of the records were from an altitude below $50 \mathrm{~m}$, and no record was from above $500 \mathrm{~m}$; mountainous regions such as the Alps, Pyrenees and Massif Central are not invaded. Local abundance can be impressive, with hundreds of specimens found in a small garden. An analysis of our new $\mathrm{COI}$ sequences, combined with published sequences of specimens from several countries, confirmed that three clades comprise the species. The first clade, "Brazil", is currently confined to this country in South America; the second clade, "Argentina 2", was found in Argentina and in Europe, only in Spain; and the third, "Argentina 1", was found in Argentina and in Europe, in Spain, Portugal, France, the United Kingdom, Italy, Belgium, and Switzerland. This suggests that two clades of $O$. nungara from Argentina have invaded Europe, with one widely spread. Discussion The present findings strongly suggest that $O$. nungara is a highly invasive species and that the 
population which has invaded several countries in Europe comes from Argentina. The wide dispersion of the species and its reported local abundance, combined with the predatory character of the species, make $O$. nungara a potential threat to the biodiversity and ecology of the native soil fauna in Europe, and probably the most threatening species of all invasive land planarians present in Europe. 
1 Obama chez moi! The invasion of metropolitan France by the land

2 planarian Obama nungara (Platyhelminthes, Geoplanidae)

4 Jean-Lou Justine ${ }^{1}$, Leigh Winsor ${ }^{2}$, Delphine Gey ${ }^{3}$, Pierre Gros ${ }^{4}$, Jessica Thévenot ${ }^{5}$

61 ISYEB, Institut de Systématique Évolution Biodiversité, UMR7205 CNRS, EPHE,

7 MNHN, UPMC, Université des Antilles, Muséum National d'Histoire Naturelle, Paris, France

82 College of Science and Engineering, James Cook University, Townsville, Queensland, 9 Australia

103 Service de Systématique moléculaire, Muséum National d'Histoire Naturelle, Paris, 11 France

124 Amateur Naturalist, Cagnes-sur-Mer, France

135 UMS Patrinat (CNRS - AFB - MNHN), Muséum National d'Histoire Naturelle, Paris, 14 France

15

16 Corresponding author: Jean-Lou Justine, justine@mnhn.fr

17 


\section{Abstract}

\section{Background}

20 Obama nungara is a species of land flatworm originating from South America; the species was

21 recently described and distinguished from a similar species, Obama marmorata. Obama nungara

22 has invaded several countries of Europe, but the extent of the invasion has not been thoroughly 23 mapped.

\section{Methods}

25 In this paper, based on a five and a half-year survey undertaken by citizen science, which yielded 26530 records from 2013 to 2018, we analysed information about the invasion of Metropolitan

27 France by $O$. nungara. We also investigated the variability of newly obtained cytochrome c 28 oxidase 1 (COI) sequences of specimens from France, Italy and Switzerland.

\section{Results}

30 Obama nungara was recorded from 72 of the 96 Departments of Metropolitan France. The

31 species is especially abundant along the Atlantic coast, from the Spanish border to Brittany, and

32 along the Mediterranean coast, from the Spanish border to the Italian border. More than half of

33 the records were from an altitude below $50 \mathrm{~m}$, and no record was from above $500 \mathrm{~m}$;

34 mountainous regions such as the Alps, Pyrenees and Massif Central are not invaded. Local

35 abundance can be impressive, with hundreds of specimens found in a small garden. An analysis

36 of our new COI sequences, combined with published sequences of specimens from several

37 countries, confirmed that three clades comprise the species. The first clade, "Brazil", is currently

38 confined to this country in South America; the second clade, "Argentina 2", was found in 
39 Argentina and in Europe, only in Spain; and the third, "Argentina 1", was found in Argentina

40 and in Europe, in Spain, Portugal, France, the United Kingdom, Italy, Belgium, and Switzerland.

41 This suggests that two clades of O. nungara from Argentina have invaded Europe, with one

42 widely spread.

\section{Discussion}

44 The present findings strongly suggest that $O$. nungara is a highly invasive species and that the

45 population which has invaded several countries in Europe comes from Argentina. The wide

46 dispersion of the species and its reported local abundance, combined with the predatory character

47 of the species, make O. nungara a potential threat to the biodiversity and ecology of the native

48 soil fauna in Europe, and probably the most threatening species of all invasive land planarians

49 present in Europe. 


\section{Introduction}

52 Several land planarians have been reported as invasive alien species in Europe (Table 1). Each

53 of these species shows distinctive features. Some are remarkable by their considerable size, such

54 as Bipalium kewense and Diversibipalium multilineatum, which can reach $30 \mathrm{~cm}$ in length

55 (Justine et al. 2018b). Some have invaded only parts of Europe, such as Arthurdendyus

56 triangulatus, mostly confined to the northern part of the British Isles (Jones et al. 2001). Some

57 are relatively rare, such as Caenoplana coerulea (Justine et al. 2014a), or inconspicuous, such as

58 the small species Marionfyfea adventor (Jones \& Sluys 2016). Only one species, A. triangulatus,

59 has been added, very recently, to the list of invasive alien species of Union concern (European

60 Union 2019).

61 This paper concentrates on one species, Obama nungara, which has already been recorded in

62 several European countries (Carbayo et al. 2016). So far, there are published records from

63 Guernsey Island, the United Kingdom (UK), Spain, Portugal, France, Belgium, and Italy, valid

64 unpublished records from Ireland and Madeira Island, and an alleged record from the

65 Netherlands (Table 2). In this paper, we add a record from Switzerland. No record is known

66 from Germany (Sluys 2019), or any country east of Germany.

67 Research on invasive species calls for the participation of the public in order to obtain

68 information on a detailed scale. Like our previous studies on invasive land flatworms (Justine et

69 al. 2014a; Justine et al. 2015; Justine et al. 2014b; Justine et al. 2018b), this research on $O$.

70 nungara was based on hundreds of reports from a large number of citizens. We acknowledge the

71 immense value of these records from citizen science (Kullenberg \& Kasperowski 2016); 
72 however, in this paper, we point out some limitations concerning the accuracy of citizen science

73 records due to bias associated with media buzz.

74 The identification of land planarians is difficult, and the name $O$. nungara itself was assigned to

75 the species as recently as 2016 (Carbayo et al. 2016). In this paper, in addition to the information

76 based on data from citizen science, we sequenced a number of specimens from various regions of

77 France to obtain COI barcodes, and analysed our sequences in the light of recent research on the

78 geographic origin of this invasive species (Lago-Barcia et al. 2019).

79 The results of this analysis suggest that the specimens found in France, Italy and Switzerland,

80 and sequenced by us, have their geographical origin in Argentina.

\section{Materials and Methods}

\section{Citizen science and collection of information}

83 Data were collected from mid-2013 to the end of 2018, a period of 5.5 years. For this study, we

84 used the same method as for our previous research on invasive flatworms (Justine et al. 2014a;

85 Justine et al. 2015; Justine et al. 2014b; Justine et al. 2018b). Briefly, a blog (Justine 2019b) and

86 a Twitter account (https://twitter.com/Plathelminthe4) were instrumental in collecting and

87 transmitting information. Reports of sightings of land planarians were received from the general

88 public and sometimes from professionals, generally by email and, since 2018, from a dedicated

89 web page (http://eee.mnhn.fr/). Inaccurate records (slugs, earthworms, leeches, and others) were

90 eliminated. Two waves of reports were received in 2014 and 2015 when we published our papers

91 on Platydemus manokwari (Justine et al. 2015; Justine et al. 2014b) and when the media reported

92 the presence of this highly invasive species in metropolitan France. Many reports were labelled 
93 as "Platydemus manokwari" or "New Guinea Flatworm" by the public; none were P. manokwari

94 in the wild in metropolitan France, and in most cases were in fact $O$. nungara.

95 Photographs received from non-professionals were studied. Obama nungara is typically 5-8

96 centimetres in length, with a brownish dorsal side (varying among specimens from orange to

97 almost black), a beige sole, and a body shape with a pointed head. In metropolitan France,

98 confusion on the basis of photographs sent by amateurs is possible only with (1) Parakontikia

99 ventrolineata, but this species is smaller and has typical longitudinal lines on its back and belly;

100 these lines are often not easily visible on photographs taken by amateurs but can be seen after

101 enhancing the contrast, and (2) P. manokwari, but this species has a typical body shape, two

102 conspicuous eyes, and a clear, pale single longitudinal line on its back. Conversely, O. nungara

103 cannot possibly be confused with Caenoplana bicolor (typical bright yellow-orange dorsal side

104 with two black longitudinal lines), Caenoplana coerulea (typical well-visible white line on the

105 back, blue sole), and the bipaliines (typical head shape, and large size for $B$. kewense and $D$.

106 multilineatum). Confusion of $O$. nungara with smaller species, such as Marionfyfea adventor,

107 Rhynchodemus spp. or Microplana spp. is unlikely. Finally, we are confident that all records

108 mentioned in this paper are O. nungara.

109 A few non-professional contributors decided, on their own initiative, to do much more than what

110 was requested and registered the number of worms they were killing over certain periods of time.

111 Some examples of this information are included here. While we are aware that these

112 observations were not performed by scientists, we see no reason why they may be erroneous, and

113 thus we believe that they are be a valuable contribution to our scientific findings. 
114 In our previous article on bipaliines (Justine et al. 2018b), after seeking authorisation from non-

115 professionals, we made a considerable effort to publish all available photographs. This was time-

116 consuming, since formal authorisation had to be collected sometimes up to 5 years after an email

117 was received. In this paper, we received a far higher number of citizen science reports than in our

118 previous paper on bipaliines (530 records vs 117). We decided that publishing all the

119 photographic information and data would make the Supplementary Files too large and was

120 probably not beneficial. Instead, we selected the best and most informative photographs.

121 Our aim was originally to collect information for metropolitan France, but a few records were

122 also obtained from neighbouring countries, namely Switzerland and Italy.

123 In an open science perspective, we have made all 530 records obtained in France public, as

124 Supplemental File 1; records have been anonymised, i.e. the names of private persons have 125 been deleted. Data will also be transferred to national databases on biodiversity and then to the 126 Global Biodiversity Information Facility (GBIF).

\section{Collection of specimens}

128 In some cases, after examining a photograph, we solicited specimens from the non-professionals

129 or professionals who reported sightings. Specimens were sent either alive or in ethanol,

130 registered in the collections of the Muséum National d'Histoire Naturelle, Paris (MNHN), and

131 processed for molecular analysis.

132 When specimens were obtained alive, they were fixed in near boiling water and preserved in $13395 \%$ ethanol. 


\section{Molecular sequences}

135 For molecular analysis, a small piece of the body $\left(1-3 \mathrm{~mm}^{3}\right)$ was taken from the lateral edge of

136 ethanol-fixed individuals. Genomic DNA was extracted using the QIAamp DNA Mini Kit

137 (Qiagen). Two sets of primers were used to amplify the COI gene. A fragment of $424 \mathrm{bp}$

138 (designated in this text as "short sequence") was amplified with the primers JB3 (=COI-ASmit1)

139 (forward 5'-TTTTTTGGGCATCCTGAGGTTTAT-3') and JB4.5 (=COI-ASmit2) (reverse 5'-

140 TAAAGAAAGAACATAATGAAAATG-3') (Bowles et al. 1995; Littlewood et al. 1997). PCR

141 reactions were performed in $20 \mu$, containing $1 \mathrm{ng}$ of DNA, $1 \times$ CoralLoad PCR buffer, $3 \mathrm{mM}$

$142 \mathrm{MgCl}_{2}, 66 \mu \mathrm{M}$ of each dNTP, $0.15 \mu \mathrm{M}$ of each primer, and 0.5 units of Taq DNA polymerase

143 (Qiagen). The amplification protocol was: $4^{\prime}$ at $94^{\circ} \mathrm{C}$, followed by 40 cycles of $94^{\circ} \mathrm{C}$ for 30 ',

$14448{ }^{\circ} \mathrm{C}$ for $40^{\prime \prime}, 72^{\circ} \mathrm{C}$ for $50^{\prime \prime}$, with a final extension at $72{ }^{\circ} \mathrm{C}$ for $7^{\prime}$. A fragment of 825 bp was

145 amplified with the primers BarS (forward 5'-GTTATGCCTGTAATGATTG-3') (Álvarez-Presas

146 et al. 2011) and COIR (reverse 5'-CCWGTYARMCCHCCWAYAGTAAA-3') (Lázaro et al.

147 2009; Mateos et al. 2013). PCR products were purified and sequenced in both directions on a 96-

148 capillary 3730xl DNA Analyzer sequencer (Applied Biosystems). Results of both analyses were

149 concatenated to obtain a COI sequence of $909 \mathrm{bp}$ in length (designated in this text as "long

150 sequence"). Sequences were edited using CodonCode Aligner software (CodonCode

151 Corporation, Dedham, MA, USA), compared to the GenBank database content using BLAST,

152 and deposited in GenBank under accession number MN529561-MN529582. For several

153 specimens, only "short" sequences were obtained (Table 3). 
154 Matrix

155 Many sequences of the COI gene of O. nungara are available in GenBank, under various species

156 names, due to confusion and the complex nomenclatural history of the species (Álvarez-Presas et

157 al. 2014; Carbayo et al. 2016; Lago-Barcia et al. 2019; Lago-Barcia et al. 2015). These

158 sequences were obtained with various primers and thus overlap only partially. We constructed a

159 matrix following three steps. Step 1: we constructed a large preliminary matrix including almost

160 all the sequences of $O$. nungara (under different names) from GenBank and selected sequences

161 of other species of Obama. We found that only a part of the COI sequence was shared by a

162 significant number of them. Step 2: we trimmed the matrix to keep only the shared part.

163 Preliminary analyses with this matrix produced trees with low support, because many of the

164 sequences from GenBank had misreads. Step 3: we deleted all sequences containing misreads.

165 The final matrix, used in this analysis, is 255 bases in length and includes 99 sequences, namely

1668 sequences of 7 Obama species (O. anthropophila, O. burmeisteri, O. carinata, O. josefi, $O$.

167 ladislavii, O. marmorata, O. maculipunctata) and 91 sequences of $O$. nungara including our 22

168 new sequences. The matrix includes sequences of $O$. nungara from Argentina, Brazil, and seven

169 countries in Europe; it is perfectly "clean" with no misreading errors or blank parts, i.e. it

170 provides information on 99 taxa for all 255 positions.

171 In an open science perspective, we have also made this matrix public as Supplemental File 2

172 with this paper; the matrix, in MEGA format (.meg) (Kumar et al. 2016), includes information

173 about "groups" (a MEGA feature), i.e. the clades found in the analysis. It is also provided in

174 FASTA format (.fasta), which does not include this information. 
175 Trees and distances

176 MEGA7 (Kumar et al. 2016) was used to evaluate distances, choose models and construct trees.

177 The best evolutionary model for the data set in our matrix, under the Bayesian Information

178 Criterion (BIC), was the Hasegawa-Kishino-Yano model with Gamma distribution (HKY $+\mathrm{G})$

179 (Hasegawa et al. 1985). The evolutionary history was inferred using the Maximum Likelihood

180 (ML) method, with 1000 bootstrap replications. The Neighbour-Joining method (Saitou \& Nei

181 1987) was also inferred for comparison, with 1000 bootstrap replications. Distances within and

182 between the clades within $O$. nungara and between these clades and the outgroup were computed

183 with various methods (Tamura-3, p-distance, Kimura-2, and Maximum Composite Likelihood)

184 (Kimura 1980; Tamura 1992; Tamura et al. 2004).

185 Population analysis

186 Haplotype networks were constructed using the same matrix as for the trees, but restricted to the

187 species $O$. nungara, i.e. a matrix with 91 taxa, 255 bases in length. We used PopART software

188 (Leigh \& Bryant 2015). In the nexus file, traits were the geographical origin of the species, with

189 number of traits (NTRAITS) set to 9, and trait labels set as: Argentina, Brazil, United Kingdom

190 (including Guernsey), Portugal, Spain, Italy, Switzerland, Belgium, and Metropolitan France.

191 The method of Templeton, Crandall and Sing (TCS) was used to infer relationships among

192 samples (Clement et al. 2002).

193 Similarly, following the open science perspective, we have made this matrix public as

194 Supplemental File 3, in nexus (.nex) format. 


\section{Results}

196 Adult specimens and/or photographs of adult specimens sent to us corresponded well with the

197 description of the external morphology and published photographs of O. nungara, including the

198 dark and light-coloured forms (Carbayo et al. 2016). None of our specimens were examined

199 histologically.

Morphology of Obama nungara from Metropolitan France

201 At rest, O. nungara is flattened and leaf-shaped (Fig. 1), and when active it is elongate with

202 parallel margins tapering gently to the anterior tip and narrowing more abruptly to a point

203 posteriorly.

204 In the living specimens examined in this study, the dorsal ground colour varied from uniform

205 light honey-brown to dark brown, with darker brown striae and stippling.

In light-coloured specimens (Figs 1, 2), poorly defined paired median dorsal longitudinal stripes

207 of dark-brown pigment are separated by a fine light brown median zone of pale ground colour,

208 without striae or stippling, that extend from the anterior tip to the posterior end. The medial

209 margins of these stripes are sharp, and the outer margins diffuse and uneven. The dark pigment

210 in the median paired stripes is concentrated over the region of the pharynx and copulatory organs

211 (Fig. 1) in the posterior body third. In the mid body, the darkly pigmented broad transverse bars

212 about a third of the width of the body are separated by narrow intervals of ground colour either

213 side of the pale medial line (Fig. 2). In some specimens, these clumps of pigmentation look like

214 "tiger stripes" and may continue anteriorly towards the tip (Fig. 3). 
215 External to these paired medial "tiger stripes", brown striae comprised of aggregations of dark

216 pigment are oriented longitudinally along the body, the colour and pattern of which give the

217 body a fine gneissic texture. A submarginal zone of light ground colour, devoid of striae or

218 stippling, borders the entire body almost to the darker brown anterior tip.

219 The ventral surface is a pale grey-cream colour (pale beige), lightest in the midline (Fig. 4).

220 A single row of eyes contours the anterior tip, crowd slightly antero-laterally, and then spread

221 dorsally, covering about one third of the body width (Fig. 5). The eyes, especially those behind

222 the anterior tip and those that extend dorsally, may exhibit a zone devoid of pigment surrounding

223 each eye, resembling small halos that are more conspicuous in darker than lighter forms.

224 The dark brown form (Fig. 6) was the most abundant colour variety of specimens examined in

225 this study. In dark brown specimens, the pale median longitudinal stripe may almost be

226 obliterated by the densely dark pigmented median stripes; the anterior tip is a light brown, and

227 the eyes, behind the anterior tip and dorsally, exhibit "haloing" (Fig. 7).

228 Living adult specimens were medium sized, ranging in length from $52 \mathrm{~mm}$ to $108 \mathrm{~mm}$ with one

229 individual measuring $68.0 \mathrm{~mm}$ long, maximum width $5.5 \mathrm{~mm}$, with the mouth $41.5 \mathrm{~mm} \mathrm{(61 \% )}$

230 and gonopore $53 \mathrm{~mm}$ (77.9\%) behind the anterior tip (measured on a photograph).

231 A number of preserved and sequenced specimens were measured; measurements are given in

$232 \mathrm{~mm}$, as length (L), distance of mouth from anterior tip (G), distance of gonopore from anterior

233 tip (G), and percentages: MNHN JL092A, L 40, M 25 (62.5\%), G 33 (82.5\%); MNHN JL094, L

234 28, M 15 (53.6\%), G 20 (71.4\%); MNHN JL101A, L 40, M 25 (62.5\%), G 33 (82.5\%); MNHN

235 JL101B, L 48, M 28 (58.3\%), G 38 (79.2\%). 
236 Cocoons were bright red when freshly laid (Fig. 8), tanning to dark brown over 3 days (Fig. 9).

237 Cocoons took $13-17$ days to hatch at about $20^{\circ} \mathrm{C}$. Three juveniles freshly emerged from their

238 cocoon, laid by MNHN JL092 (Fig. 10), measured $10 \times 1.4 \mathrm{~mm}, 7 \times 1.1 \mathrm{~mm}$, and $4.1 \times 1.3 \mathrm{~mm}$.

239 They were light cream in colour with fine dark brown stippling, with some aggregation of the

240 fine spots towards the mid-dorsum delineating a fine discontinuous median unpigmented dorsal

241 stripe, with an indication of dark transverse bars. The anterior tips were dark grey, and ventral

242 surfaces pale grey.

243 As previously explained, we received hundreds of photographs of adult specimens taken by non-

244 professional contributors and cannot show all images here. However, most can be retrieved from

245 the Twitter feed of one of the authors (@Plathelminthe4). We show here only two photographs

246 of special interest. Figure 11 is a single specimen which shows the dark-brown pattern; this

247 single specimen was found in Paris in December 2013, and this photo was therefore used by

248 many media channels; the specimen was deposited in our collection as MNHN JL094, and

249 sequenced (Table 3). Figure 12 is a photograph of a plastic box with its surface covered with

250 adult specimens, which illustrates the abundance of the species in some gardens. Figure 13

251 includes a sample of 9 photographs and shows the variety of images of $O$. nungara received

252 from various contributors, with and without scales, sometimes in the natural habitat or, on the

253 contrary, arranged on a coloured surface by photographers.

254 Information obtained from citizen science: presence

255 Our database of valid records of land flatworms received from mid-2013 to December 2018

256 contains more than 1000 records, after elimination of species that are not flatworms. We found

257 that $\mathbf{5 3 0}$ valid reports, i.e. over half of them, concerned $O$. nungara in Metropolitan France. This 
258 is therefore the most often recorded species. Most reports were from non-professionals, while a

259 few were from professionals or scientists.

260 Figure 14 is a map of these records in metropolitan France, with each record shown as a dot on

261 the map. The map includes general colour-coded information on altitude. The records were most

262 abundant along the Atlantic and Mediterranean coasts; mountainous areas (Alps, Pyrenees,

263 Massif Central) were devoid of records, which were mainly in the plains. The north-eastern

264 quarter of the country, which has a colder climate, had fewer records than the other three

265 quarters; however, there was a concentration of records around Paris.

266 In Figure 14, a number of records may be overlooked when dots are superposed, when several

267 records were received from the same locality, or when they were from neighbouring localities.

268 Figure 15 is a map of metropolitan France with records shown as numbers in each Department

269 (Departments are the main administrative divisions in France, with a current number of 96 for

270 Metropolitan France). Among the 96 Departments, 72 (75\%) had records. The Departments with

271 the most records were Gironde and Finistère (40-80 records), on the Atlantic Coast, and most

272 Departments along the Atlantic Coast from the Spanish border to Brittany had more than 30

273 records. One noticeable case is Haute-Garonne, which is not on the coast but stands out from the

274 neighbouring Departments with more than 40 records. Only 24 Departments had no records; they

275 are mainly in the Massif Central and the north-eastern quarter of the country. In the discussion,

276 we briefly comment on these results in view of population densities in various Departments.

277 We used our database to investigate the influence of altitude. Figure 16 shows a chart of the

278 number of records against increasing altitude. More than half of the records were from an

279 altitude below $50 \mathrm{~m}$; records above $250 \mathrm{~m}$ were rare, and no records were from above $500 \mathrm{~m}$. 
280 Information obtained from citizen science: abundance

281 In addition to the numerous "one time" records mentioned above, we received two reports from

282 non-professionals who counted the flatworms in their gardens over a long period.

283 Sylvain Petiet, from Cabanac-et-Villagrains (Gironde, south-western France), collected and

284 destroyed specimens every day in his garden from May to August 2014; he estimated the

285 invaded part to be about $300 \mathrm{~m}^{2}$, in a larger garden about 5,000 $\mathrm{m}^{2}$ in surface. He collected a

286 total of 924 specimens: from 03 May 2014 to 29 May2014 (26 days), 180 specimens (6.9/day),

287 and from 29 May 2014 to 22 August 2014 (85 days), 744 specimens (8.7/day). After that, he

288 reported in 2014 that flatworms were still as numerous in the garden. Figure $\mathbf{1 3}$ is a photograph

289 of a box of worms collected in May 2015 by Sylvain Petiet. Interestingly, he reported in 2019

290 that no flatworms were present.

291 Michel Hir, from Brest (Finistère, north-western France), collected and destroyed specimens

292 every day in his garden from November 2015 to May 2016 (Table 4). His garden is $175 \mathrm{~m}^{2}$ in

293 surface area. He mentioned that the garden was enclosed by 2-metre high walls and observed that

294 specimens were only occasionally seen on the wall but never more than $40 \mathrm{~cm}$ in height, so we

295 can consider that all specimens found originated from reproduction of species from his own

296 garden, without invasion from the neighbouring areas. He collected a total of 1442 specimens

297 (10.2/day). After that, he reported that flatworms were still as numerous in the garden.

298 A simple calculation from Michel Hir's data for the highest period he recorded (November: 19

299 worms $/$ day $/ 175 \mathrm{~m}^{2}$ ) provides an estimate of population increase due to reproduction of 1085

300 worms/hectare/day, or 0.1 worm $/ \mathrm{m}^{2} /$ day. Importantly, all these counts are based on adult 
301 individuals only, which suggests that the number of hatchlings was even higher (although

302 mortality of hatchlings was not assessed, we can assume that it is not zero).

\section{Trees and distances}

304 A tree (Fig. 17) was constructed from a matrix built from a selection of COI sequences of $O$.

305 nungara from GenBank and our own new sequences, with a selection of sequences from other

306 species as the outgroup. The matrix had 99 taxa with 255 positions and was perfectly clean, i.e.

307 without misread or blank parts.

308 The O. nungara clade included 91 sequences and had high support (ML 96\%, NJ 99\%). Because

309 of the complex nomenclatural history of the species, many specimens labelled in GenBank as

310 "Obama marmorata", and others labelled as "Obama sp." or "Obama sp. 6", were included

311 within the O. nungara clade - we consider these sequences as representatives of $O$. nungara.

312 Within the O. nungara clade, there were three clades, each with high support. These three clades

313 are outlined in the simplified tree in Figure 18. We chose the names for the clades according to

314 the country of origin of sequences from South America.

315 The first clade (herein named clade "Argentina 1", ML 89\%, NJ 91\%) is robust and includes

316 most sequences of $O$. nungara, including specimens from Argentina and most specimens from

317 European countries, including all specimens from France. This "Argentina 1" clade is sister-

318 group to a clade (with low support) which includes two clades with high support, a clade (herein

319 named clade "Argentina 2", ML 87\%, NJ 86\%) that includes specimens exclusively from

320 Argentina and Spain, and a clade (herein named clade "Brazil", ML 98\%, NJ 98\%) that includes

321 exclusively specimens from Brazil. 
322 Distances between and within the clades that constitute the $O$. nungara clade are detailed in

323 Table 5. The mean distances within the clades were low, ranging from $0.39-1.18 \%$ according to

324 the clade and method used, and the mean distances between clades were 3.62-5.39\%, according

325 to the clade and method used. Mean distances between the three $O$. nungara clades and the

326 outgroup were higher, ranging from $9.25-17.61 \%$, according to the clade and method used. This

327 suggests that $O$. nungara is composed of three distinct clades, each with relatively low, albeit

328 present, internal variation.

329 Haplotype network

330 The matrix for the network included 91 sequences of $O$. nungara from 9 countries; the matrix

331 had 255 positions and was clean, without misread or blank parts. The haplotype network is

332 shown in Figure 19. The haplotype network analysis recognised 19 haplotypes for O. nungara.

333 Three main networks were obtained.

334 The most important network in terms of numbers of sequences included 10 haplotypes, in which

335 three were represented by more than 10 samples and the 6 others were either singletons (5) or

336 with two samples (1). This large network included specimens from Argentina, and seven

337 European countries including Spain, Portugal, France, Belgium, the UK, Italy and Switzerland; it

338 corresponded to clade "Argentina 1" of the tree. The three main haplotypes within this network

339 had different geographical compositions. The largest haplotype included representatives from

340 Argentina and 6 European countries, the second had specimens from Argentina and 4 European

341 countries, and the third had only specimens from Spain; among the small groups, 5 are from

342 Spain and 2 from France. 
343 Another network included 5 haplotypes, each with 1-2 specimens, and corresponded to clade

344 "Argentina 2" of the tree; specimens were only from Argentina (4 haplotypes) and Spain.

345 One network, with 4 haplotypes, included only specimens from Brazil and coincided with the

346 "Brazil" clade found in the tree.

347 Finally, most specimens from Europe belonged to the "Argentina 1" clade, with only a few

348 specimens from Spain in the "Argentina 2" clade; no specimens from Europe were found within

349 the "Brazil" clade.

350 Reports by citizen science and their significance

351 In Figure 20, we report the number of findings of $O$. nungara in Metropolitan France each year

352 from 2013 to 2018 . Two peaks are visible, in 2014 and 2018.

353 In Figure 21, we show the findings for O. nungara in Metropolitan France arranged by month,

354 for all our records from 2013 to 2018. The histogram shows a tendency to a general peak in late 355 spring (May and June) and another, weaker, peak in autumn (October); records during winter are 356 minimal.

357 In our daily work at validating and compiling records from citizen science, our attention was

358 drawn to the fact that mentions of land flatworms in the media were immediately followed by the

359 arrival of numerous records, followed by a calmer period when media reports were not released.

360 In Figure 22, we show the variation of weekly records in 2018 for all species of land flatworms,

361 including $O$. nungara (which represents about half of the records). The peak of weeks 21-24 in

3622018 coincides with the publication of our paper in PeerJ about bipaliines, which benefited from 
363 a press release and received strong interest from the media in France. These observations are

364 commented in the discussion.

\section{Discussion}

366 Populations of Obama nungara and the invasion of Europe

367 Our results confirm the conclusions of Lago-Barcia et al. (2019) on the routes of invasion of $O$.

368 nungara. In the continent of origin, South America, there are three known populations of $O$.

369 nungara, two in Argentina, namely "Argentina 1" and "Argentina 2" and one in Brazil, namely

370 "Brazil". Only specimens with sequences identical or close to members of the populations

371 "Argentina 1" (in seven countries) and "Argentina 2" (only in Spain) were found in Europe. The

372 invasion of several countries of Europe has its origin in Argentina, not Brazil. Our analysis of

373 available sequences, at the present time, suggests that the "Argentina 2" population in Europe is

374 still restricted to Spain, while the "Argentina 1" population is widely present in most invaded

375 European countries.

376 Our analysis confirms published findings (Lago-Barcia et al. 2019), with specimens from

377 additional countries. Our matrix includes a higher number of sequences of $O$. nungara (91 vs.

378 66). We did not use exactly the same sequences and the same matrix, because of the limitations

379 detailed in Materials and Methods, with sequences from different authors not overlapping;

380 however, we found similar results for the origin of the invasion. Our matrix contains a lower

381 number of sequences from Argentina, because we eliminated sequences with misreads, but this

382 did not diminish the value of the interpretation. The networks in our analysis correspond well

383 with those of the previous study, with "Argentina 1" = "Network 3", "Argentina 2 = "Network 
384 1", and "Brazil" = "Network 2". In addition to the previous study, our study includes sequences

385 from a larger number of countries and several new sequences from France. We found a total of

38619 haplotypes (vs. 21) for O. nungara, including 10 haplotypes in the largest network,

387 "Argentina 1" compared to 11 in the corresponding "Network 3" in the previous study. Our

388 results therefore confirm and expand the conclusions of Lago-Barcia et al. (2019).

389 For future studies on O. nungara, COI sequences, with a large amount of data available, will

390 certainly remain a primary choice, but more variable sequences will be useful for a finer analysis

391 of the invasion.

392 The extent of the invasion in Metropolitan France and Europe

393 As shown on the maps (Figs 14, 15), O. nungara has invaded a large part of Metropolitan France

394 and is found in 72 of the 96 Departments of Metropolitan France. The species was also recorded

395 in mainland Europe in Spain, Portugal, Italy, Belgium, possibly the Netherlands, and

396 Switzerland, and on European islands such as Guernsey, Great Britain, and Ireland in the North,

397 and Corsica in the Mediterranean Sea (Table 2), as well as Madeira in the North Atlantic. The

398 species is seemingly absent from Germany (Sluys 2019), but given that several of our records in

399 Metropolitan France are just a few kilometres from the German border, it is likely that the

400 species will be recorded in this country very soon. No records were found from countries east of 401 Germany.

402 Many reports of new invasions by various species of land flatworms are published every year

403 (Chaisiri et al. 2019; Hu et al. 2019; Jones 2019; Justine et al. 2018a; Justine et al. 2019;

404 Prozorova \& Ternovenko 2018; Rodríguez-Cabrera \& Torres 2019; Soors et al. 2019;

405 Vardinoyannis \& Alexandrakis 2019). As for other land planarians (Sluys 2016), the origin of 
406 the invasion by $O$. nungara is likely to be the international trade of plants, since adult planarians

407 and cocoons can easily travel in pot plants. After an invasion from Argentina (probably with

408 multiple worms) to an unknown country (or perhaps several countries) in Europe, the species

409 was then transmitted from country to country in Europe through intra-European plant trade, and

410 again within each country by the same ways.

411 More than half of the records of O. nungara in Metropolitan France were from an altitude lower

412 than $50 \mathrm{~m}$, records above $250 \mathrm{~m}$ were very rare, and there was no record above $500 \mathrm{~m}$ (Fig. 16).

413 While most of this altitude information might seem redundant with the geographical information

414 (coastal localities are at low altitude), we believe that the absence of $O$. nungara above $500 \mathrm{~m}$ is

415 significant. We also note that most, if not all, reports in other European countries are from

416 localities at a low altitude; interestingly, the single report from Switzerland, a mountainous

417 country, is from Geneva, with an altitude $(369-458 \mathrm{~m})$ below the limit found in France. Although

418 more detailed studies are probably needed, we propose the hypothesis that the limiting factor is

419 freezing, more likely at higher altitudes. This might be an important factor limiting the species in

420 its invasion of Europe.

421 Our information on the local abundance of the species, although based only on data from non-

422 professionals, is impressive. Hundreds of specimens in a single garden have been reported

423 several times, and the counts by Michel Hir and Sylvain Petiet indicate that an invaded area can

424 produce, by reproduction, an estimate of 1000 adult individuals/day/hectare.

425 Geographical and temporal biases in citizen science data: a warning

426 Data from citizen science were instrumental in our research. It has been shown that recordings of

427 invasive species is one of the major fields of research using citizen science (Kullenberg \& 
428 Kasperowski 2016). However, the quality of data obtained from citizen science requires

429 assessment (Kosmala et al. 2016), and we would like to point out two biases in our data:

430 geographical and temporal.

431 Geographical biases happen when more reports are obtained from an area where more members

432 of the public provide reports, although this area does not actually harbour more specimens. This

433 is evident on our map (Fig. 14) for the reports from the area around Paris. The Paris region

434 harbours $18 \%$ of the French population, with a much higher density of people compared to the

435 density in the rest of the country. However, it could be argued that cities are warmer than the

436 countryside surrounding them, therefore providing better conditions for the species in winter.

437 Two high-density regions on our maps (Fig. 15) probably reflect higher human population

438 densities: the Gironde Department includes Bordeaux, the $6^{\text {th }}$ largest French city in terms of

439 population, and Haute-Garonne includes Toulouse Metro Area, the $4^{\text {th }}$ largest urban area in

440 France in terms of population. Another possible bias that is not easy to quantify, is the cultural

441 difference between urban populations that are accustomed to using smartphones and social

442 media, and rural populations, often older, where people are possibly less familiar with modern

443 technology. We have anecdotal stories about this cultural gap. In some rare cases, we received

444 records of flatworms as photographs printed on paper and sent by post - this was only from rural

445 populations, not from cities. We also had discussions by telephone on how to ask a grandson to

446 use his smartphone to record the flatworms found in his grandparents' garden - the grandparents

447 themselves having only a landline. Clearly, records from citizen science should be considered

448 with this bias in mind. Cultural differences between urban and rural populations in France are

449 probably relatively minor compared to what can be found in other countries; a recent study in

450 Thailand found that more reports of Platydemus manokwari were received from the great shore 
451 cities than from the inland (Chaisiri et al. 2019), which should be, in our opinion, interpreted

452 more as a geographical/cultural bias, rather than a preferred location of the species.

453 Temporal biases occur when more reports are received at certain times of the year,

454 independently of the actual abundance of the species. In our daily work in receiving emails from 455 non-professionals, we noted that waves of records were received within days of certain media 456 reports featuring our research (either radio, television or newspapers). The media effect was

457 visible even though the species featured in the media was different (i.e. bipaliines, or Platydemus 458 manokwari, vs other land flatworms). In fact, the emails we received often mentioned the recent 459 media report which provided the information; this was even more visible when regional 460 newspapers were involved, with waves of records coming from certain regions only. Figure 22 461 shows that weeks \#22-24 in 2018 provided a high number of records; clearly, this was after our 462 paper about bipaliines was published (Justine et al. 2018b). This paper was accompanied by a 463 short article in French in the open-access media The Conversation (Justine 2018), which was 464 read more than 1,000,000 times in one week (Justine 2019a), and produced a number of 465 mentions in the national media (Bardou 2018; Morin 2018; Vidard 2018) and the media in other 466 countries (Gabbatiss 2018; Guarino 2018). However, May is also a period when O. nungara is 467 abundant, and, in the Northern Hemisphere, a period when amateur gardeners spend much time 468 in their garden. Figure 21 shows the number of records of the species each month during the 469 five-year survey. Although it is probably true that O. nungara is less abundant in winter 470 (December-February) we do not know with certainty whether this is an actual decrease of 471 abundance, or whether the number of records is low simply because this is a period when 472 gardeners spend less time in their gardens. Similarly, the peak of abundance in May and June is 
473 probably genuine, but the data were biased by the abundance of records in May 2018 mentioned

474 above (Fig. 22).

475 These geographical and temporal biases might hamper a thorough analysis of the data from

476 citizen science; again, we insist that citizen science data are of extreme interest, but their

477 interpretation should never neglect these possible biases.

\section{Conclusion}

479 In this paper, we analysed data from citizen science over a five-and-a-half-year period and 480 showed that $O$. nungara has invaded more than two-thirds of Metropolitan France, except for

481 mountainous areas. We also found that local abundance in gardens can reach up to hundreds of

482 specimens, and that the specimens in an invaded garden can produce, by sexual reproduction, 483 numerous progeny.

484 Our molecular barcoding study based on newly acquired and GenBank sequences of the 485 cytochrome c oxidase 1 gene confirmed that the populations of $O$. nungara found in Europe are 486 similar to two populations from Argentina (but not from Brazil) (Lago-Barcia et al. 2019). We 487 also confirmed or showed that a single population has invaded Spain, Portugal, France, the UK, 488 Italy, Belgium and Switzerland.

489 Although more than 10 species of land flatworm have invaded Europe (Table 1), no other 490 species is comparable with $O$. nungara in terms of the size of the invaded territories: mainland 491 Europe in Portugal, Spain, France, Italy, Belgium and Switzerland, islands in Europe such as 492 Britain, Ireland and Guernsey, as well as Corsica in the Mediterranean, and Madeira in the North 
493 Atlantic; and in terms of recorded densities of animals in invaded areas. This clearly designates

494 O. nungara as the most important invasive species of land flatworms in Europe.

495 Since the species has predatory habits on species of the soil fauna, its ecological impact is

496 probably high, but has yet to be studied. Also, since the species seems to have a large spectrum

497 of prey in its native area (Boll \& Leal-Zanchet 2016), including earthworms and molluscs, more

498 studies are needed to determine which species, and in which quantities, are most preyed upon in

499 Europe. Molecular methods (Cuevas-Caballé et al. 2019) are available for obtaining this

500 information.

501

502 Acknowledgements

503 We thank all the members of the general public who participated in the survey; those who sent

504 specimens are particularly thanked. Names of non-professionals, and sometimes scientists, who

505 provided photographs and/or specimens are indicated in Tables and Figures. Two contributors,

506 Sylvain Petiet and Michel Hir, kindly provided their results for counting. The support of various

507 Regional federations for the control of pests (Fédérations Régionales de Défense contre les

508 Organismes Nuisibles, FREDON) is acknowledged. Hugh Jones (NHM, London) kindly

509 provided unpublished information about records in the UK, Ireland and Madeira. Olivier

510 Gargominy (MNHN, Paris) kindly identified a snail from photographs. 


\section{References}

513 Aldred J. 2016. Warning over invasive flatworm posing threat to UK wildlife. The Guardian. $514 \quad$ London, UK.

515 Álvarez-Presas M, Carbayo F, Rozas J, and Riutort M. 2011. Land planarians (Platyhelminthes)

516 as a model organism for fine-scale phylogeographic studies: understanding patterns of

517 biodiversity in the Brazilian Atlantic Forest hotspot. Journal of Evolutionary Biology $518 \quad 24: 887-896$

519 Álvarez-Presas M, Mateos E, Tudo A, Jones H, and Riutort M. 2014. Diversity of introduced 520 terrestrial flatworms in the Iberian Peninsula: a cautionary tale. PeerJ 2:e430.

521 Bardou F. 2018. Comment les vers plats géants ont colonisé les jardins français. Libération. Paris, $522 \quad$ France.

523 Boag B, Palmer LF, Neilson R, and Chambers SJ. 1994. Distribution and prevalence of the 524 525 predatory planarian Artioposthia triangulata (Dendy) (Tricladida: Terricola) in Scotland. Annals of Applied Biology 124:165-171.

Boll PK, and Leal-Zanchet AM. 2016. Preference for different prey allows the coexistence of several land planarians in areas of the Atlantic Forest. Zoology 119:162-168.

Bowles J, Blair D, and McManus DP. 1995. A molecular phylogeny of the human schistosomes. Molecular Phylogenetics and Evolution 4:103-109. 
530 Breugelmans K, Quintana Cardona J, Artois T, Jordaens K, and Backeljau T. 2012. First report of

531 the exotic blue land planarian, Caenoplana coerulea (Platyhelminthes, Geoplanidae), on

532 Menorca (Balearic Islands, Spain). Zookeys 199:91-105.

533 Carbayo F, Alvarez-Presas M, Jones HD, and Riutort M. 2016. The true identity of Obama 534 (Platyhelminthes: Geoplanidae) flatworm spreading across Europe. Zoological Journal of 535 the Linnean Society 177:5-28.

536 Chaisiri K, Dusitsittipon S, Panitvong N, Ketboonlue T, Nuamtanong S, Thaenkham U, Morand S, and Dekumyoy P. 2019. Distribution of the newly invasive New Guinea flatworm Platydemus manokwari (Platyhelminthes: Geoplanidae) in Thailand and its potential role as a paratenic host carrying Angiostrongylus malaysiensis larvae. Journal of Helminthology

541 Clement M, Snell Q, Walke P, Posada D, and Crandall K. 2002. TCS: estimating gene genealogies. Proceedings of the 16th International Parallel and Distributed Process Symposium 2:184. Fort Lauderdale, Florida.

544 Cuevas-Caballé C, Riutort M, and Álvarez-Presas M. 2019. Diet assessment of two land planarian species using high-throughput sequencing data. Scientific Reports 9:8679.

546 de Beauchamp P. 1962. Platydemus manokwari n. sp., planaire terrestre de la Nouvelle-Guinée Hollandaise. Bulletin de la Societe Zoologique de France 87:609-615. Victoria 4:35-38. 
550 Dendy A. 1895. Notes on New Zealand Land Planarians: Part II. Transactions of the Royal Society

$551 \quad$ of New Zealand 28:210-214.

552 European Union. 2019. Commission implementing regulation (EU) 2019/1262 of 25 July 2019

553

554

555

556

557

558

559

560

561

562

563

564

565

566 amending Implementing Regulation (EU) 2016/1141 to update the list of invasive alien species of Union concern. Official Journal of the European Union:26.27.2019, 2199/2011.

Gabbatiss J. 2018. Giant predatory worms invading France and threatening local wildlife. The Independent. London, UK.

Guarino B. 2018. Giant predatory worms invaded France, but scientists just noticed them. Washington Post. Washington, DC.

Hasegawa M, Kishino H, and Yano T-a. 1985. Dating of the human-ape splitting by a molecular clock of mitochondrial DNA. Journal of Molecular Evolution 22:160-174.

Hu J, Yang M, Ye ER, Ye Y, and Niu Y. 2019. First record of the New Guinea flatworm Platydemus manokwari (Platyhelminthes, Geoplanidae) as an alien species in Hong Kong Island, China. Zookeys 873:1-7.

Jones HD. 1999. A new genus and species of terrestrial planarian (Platyhelminthes; Tricladida; Terricola) from Scotland, and an emendation of the genus Artioposthia. Journal of Natural History 33:387-394.

Jones HD. 2019. Another alien terrestrial planarian in the United Kingdom: Australopacifica atrata (Steel, 1897)(Platyhelminthes: Tricladida: Continenticola). Zootaxa 4604:575-587. 
569 Jones HD, Santoro G, Boag B, and Neilson R. 2001. The diversity of earthworms in 200 Scottish

570 fields and the possible effect of New Zealand land flatworms (Arthurdendyus triangulatus)

$571 \quad$ on earthworm populations. Annals of Applied Biology 139:75-92.

572 Jones HD, and Sluys R. 2016. A new terrestrial planarian species of the genus Marionfyfea 573 (Platyhelminthes: Tricladida) found in Europe. Journal of Natural History 50:2673-2690.

574 Justine J-L. 2018. Des vers géants prédateurs envahissent les jardins français. Dans l'indifférence.

575 . The Conversation, 22 mai 2018 https://theconversationcom/des-vers-geants-predateurs576 envahissent-les-jardins-francais-dans-lindifference-96241.

577 Justine J-L. 2019a. Analytics for paper published in The Conversation "Des vers géants prédateurs 578 ..." May 2018.pdf. figshare. Dataset. https://doi.org/10.6084/m9.figshare.10271432.v1.

579 Justine J-L. 2019b. Plathelminthes terrestres invasifs. Blog (in French). 580 https://sites.google.com/site/jljjustine/plathelminthe-terrestre-invasif.

581 Justine J-L, Lemarcis T, Gerlach J, and Winsor L. 2018a. First report of the land planarian 582 Endeavouria septemlineata (Hyman, 1939) (Platyhelminthes, Tricladida, Continenticola, 583 Geoplanidae) in French Polynesia. Zootaxa 4450:297-300.

584 Justine J-L, Théry T, Gey D, and Winsor L. 2019. First record of the invasive land flatworm 585 Bipalium adventitium (Platyhelminthes, Geoplanidae) in Canada. Zootaxa 4656:591-595. France. Phytoma:28-32 doi:10.6084/m6089.figshare.1447202. 
588 Justine J-L, Winsor L, Barrière P, Fanai C, Gey D, Han AWK, La Quay-Velazquez G, Lee BPY-

589 H, Lefevre J-M, Meyer J-Y, Philippart D, Robinson DG, Thévenot J, and Tsatsia F. 2015.

590 The invasive land planarian Platydemus manokwari (Platyhelminthes, Geoplanidae):

591 records from six new localities, including the first in the USA. PeerJ 3:e1037.

592 Justine J-L, Winsor L, Gey D, Gros P, and Thévenot J. 2014b. The invasive New Guinea flatworm 593 Platydemus manokwari in France, the first record for Europe: time for action is now. PeerJ $594 \quad 2: \mathrm{e} 297$.

595 Justine J-L, Winsor L, Gey D, Gros P, and Thévenot J. 2018b. Giant worms chez moi! 596 Hammerhead flatworms (Platyhelminthes, Geoplanidae, Bipalium spp., Diversibipalium spp.) in metropolitan France and overseas French territories. PeerJ 6:e4672.

Kimura M. 1980. A simple method for estimating evolutionary rates of base substitutions through comparative studies of nucleotide sequences. Journal of Molecular Evolution 16:111-120.

Kosmala M, Wiggins A, Swanson A, and Simmons B. 2016. Assessing data quality in citizen 601 science. Frontiers in Ecology and the Environment 14:551-560.

602

Kubota S, and Kawakatsu M. 2010. Distribution record of a single species of the collective group Diversibipalium (Plathelminthes, Tricladida, Continenticola, Geoplanidae, Bipaliinae) in Wakayama Prefecture, Honshu, Japan, with a taxonomic note of new higher classification 605 of the Tricladida. Nanki Seibutsu 52:97-101.

Kullenberg C, and Kasperowski D. 2016. What is citizen science? - a scientometric meta-analysis. PLoS ONE 11:e0147152. 
608 Kumar S, Stecher G, and Tamura K. 2016. MEGA7: Molecular Evolutionary Genetics Analysis 609 version 7.0 for bigger datasets. Molecular Biology and Evolution 33:1870-1874.

610 Lago-Barcia D, Fernández-Álvarez FÁ, Brusa F, Rojo I, Damborenea C, Negrete L, Grande C, 611 and Noreña C. 2019. Reconstructing routes of invasion of Obama nungara 612 (Platyhelminthes: Tricladida) in the Iberian Peninsula. Biological Invasions 21:289-302.

613 Lago-Barcia D, Fernández-Álvarez FA, Negrete L, Brusa F, Damborenea C, Grande C, and 614 Noreña C. 2015. Morphology and DNA barcodes reveal the presence of the non-native land 615 planarian Obama marmorata (Platyhelminthes: Geoplanidae) in Europe. Invertebrate $616 \quad$ Systematics 29:12-22.

617 Lázaro EM, Sluys R, Pala M, Stocchino GA, Baguñà J, and Riutort M. 2009. Molecular barcoding 618 and phylogeography of sexual and asexual freshwater planarians of the genus Dugesia in 619 the Western Mediterranean (Platyhelminthes, Tricladida, Dugesiidae). Molecular 620 Phylogenetics and Evolution 52:835-845.

Leigh JW, and Bryant D. 2015. POPART: full-feature software for haplotype network 622 construction. Methods in Ecology and Evolution 6:1110-1116.

Littlewood DTJ, Rohde K, and Clough KA. 1997. Parasite speciation within or between host species? - Phylogenetic evidence from site-specific polystome monogeneans. International Journal for Parasitology 27:1289-1297.

Makino N, and Shirasawa Y. 1983. Morphological and ecological comparison with two new 627 species of elongated slender land planarians have several stripes and their new scientific 628 names. Bulletin of Tokyo Medical College 9:69-83 [In Japanese, English summary]. 
629 Mateos E, Tudó A, Álvarez-Presas M, and Riutort M. 2013. Planàries terrestres exòtiques a la 630 Garrotxa. Annals de la Delegació de la Garrotxa de la Institució Catalana d'Història $631 \quad$ Natural 6:67-73.

632 Mazza G, Menchetti M, Sluys R, Solà E, Riutort M, Tricarico E, Justine J-L, Cavigioli L, and Mori 633 E. 2016. First report of the land planarian Diversibipalium multilineatum (Makino \& Shirasawa, 1983) (Platyhelminthes, Tricladida, Continenticola) in Europe. Zootaxa

636 Morin H. 2018. Des vers géants envahissent la France. Le Monde. Paris, France.

637 Moseley H. 1877. Notes on the structure of several forms of land planarians, with a description of 638 two new genera and several new species, and a list of all species at present known. 639 Quarterly Journal of Microscospical Science 17:273-292.

640 Moseley HN. 1878. Description of a new species of land-planarian from the hothouses at Kew 641 Gardens. Annals and Magazine of Natural History 1:237-239.

642 Prozorova LA, and Ternovenko VA. 2018. [Rare and new species from the Far Eastern Marine 643 Reserve. 2. Land Planarians (Platyhelminthes: Tricladida: Continenticola)] Редкие и

646 Rodríguez-Cabrera TM, and Torres J. 2019. New locality records of Bipalium kewense 647 (Platyhelminthes: Tricladida: Geoplanidae) in Cuba. Poeyana 508:38-41. 
648 Saitou N, and Nei M. 1987. The neighbor-joining method: a new method for reconstructing 649 phylogenetic trees. Molecular Biology and Evolution 4:406-425.

650 Sluys R. 2016. Invasion of the Flatworms. American Scientist 104:288-295.

651 Sluys R. 2019. Klasse Turbellaria - Strudelwürmer. In: Klausnitzer B, ed. Stresemann 652 Exkursionsfauna von Deutschland Band 1: Wirbellose (ohne Insekten). Berlin, Heidelberg: Springer Berlin Heidelberg, 59-69.

654

655

656

657

659

660

661

662

663

664

665

Soors J, Van den Neucker T, Halfmaerten D, Neyrinck S, and De Baere M. 2019. On the presence of the invasive planarian Obama nungara (Carbayo, Álvarez-Presas, Jones \& Riutort, 2016) (Platyhelminthes: Geoplanidae) in an urban area in Belgium. Belgian Journal of Zoology 149:43-47.

Steel T. 1897. Australian land planarians: descriptions of new species and notes on collecting and preserving. Proceedings of the Linnean Society of New South Wales 22:104-119.

Tamura K. 1992. Estimation of the number of nucleotide substitutions when there are strong transition-transversion and $\mathrm{G}+\mathrm{C}$-content biases. Molecular Biology and Evolution 9:678687.

Tamura K, Nei M, and Kumar S. 2004. Prospects for inferring very large phylogenies by using the neighbor-joining method. Proceedings of the National Academy of Sciences of the United States of America 101:11030-11035. 
666 Vardinoyannis K, and Alexandrakis G. 2019. First record of the land planarian Caenoplana bicolor 667 (Graff, 1899) (Platyhelminthes, Tricladida, Continenticola) in Greece. BioInvasions $668 \quad$ Records 8:500-504.

669 Vidard M. 2018. La menace des vers géants. France Inter (National French Radio). Paris: Radio $670 \quad$ France.

671 von Graff L. 1899. Monographie der Turbellarien. II. Tricladida, Terricola (Landplanarien). 672 Leipzig: Englemann.

673 Winsor L. 1991. A provisional classification of Australian terrestrial geoplanid flatworms 674 (Tricladida: Terricola: Geoplanidae). Victorian Naturalist (Blackburn) 108:42-49.

675

676 
Figure 1

An example of the pale coloured form of Obama nungara at rest.

Specimen MNHN JL055 from Cagnes-sur-Mer, Alpes-Maritimes. Photo by Pierre Gros.

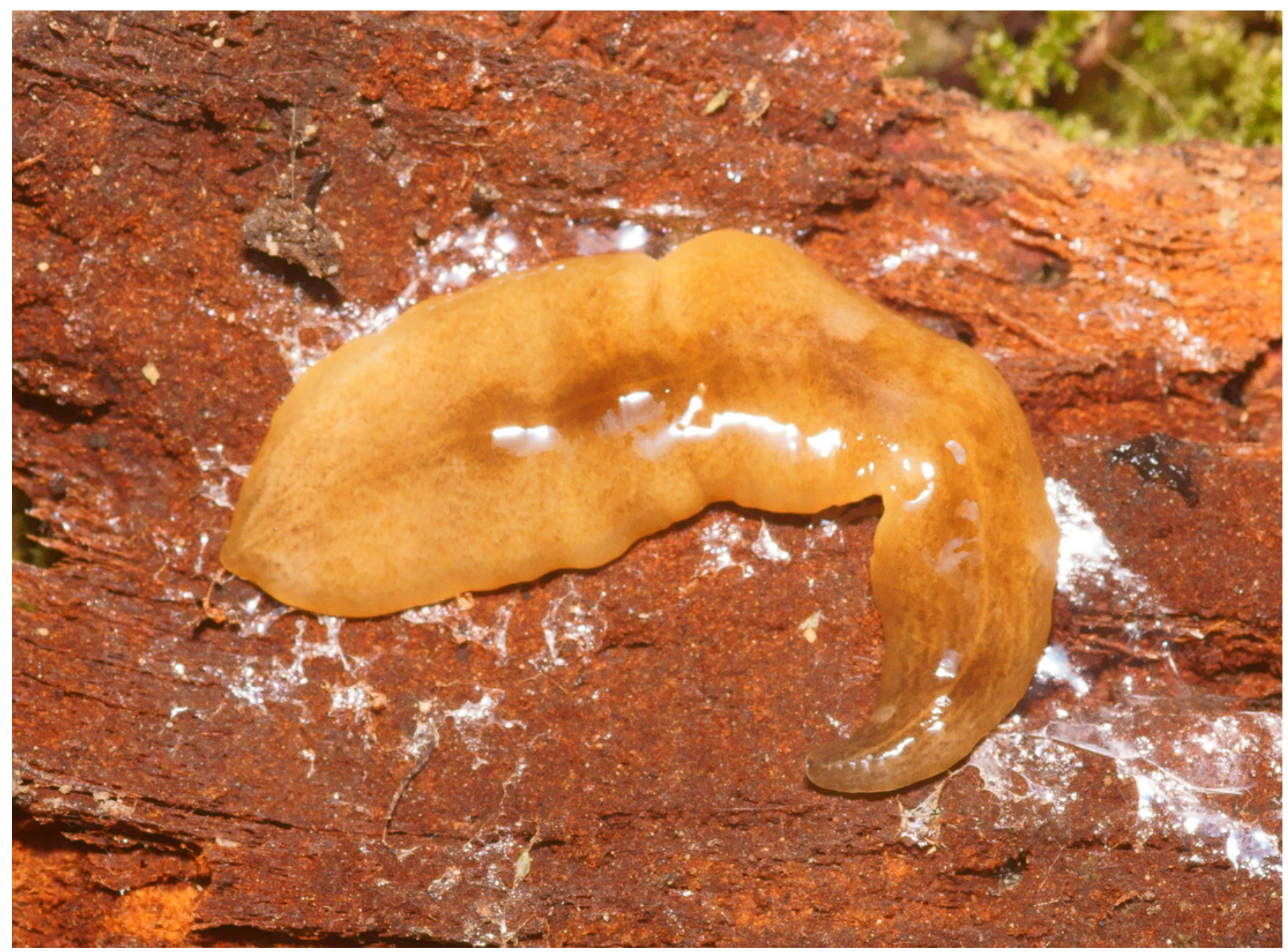




\section{Figure 2}

Pale-yellow form of Obama nungara, feeding on a snail.

The specimen shows transverse aggregations of pigment either side of the pale mid dorsal stripe. This specimen is feeding on a snail (Theba pisana), and the dorsal puckering results from protrusion of the pharynx into the snail. Specimen from Cagnes-sur-Mer, AlpesMaritimes. Photo by Pierre Gros.

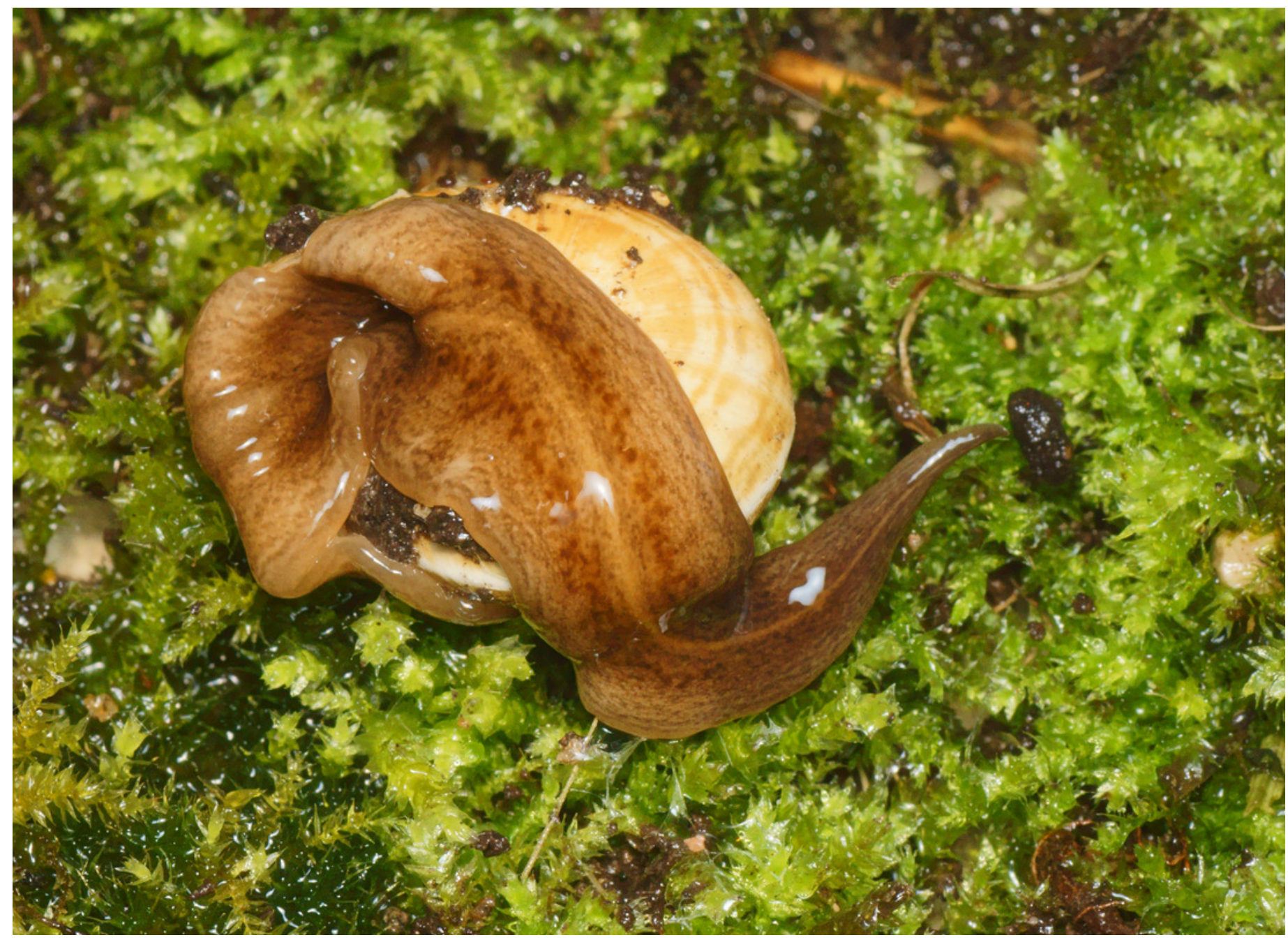


Figure 3

Dorsal view of Obama nungara.

This specimen shows pronounced dorsal "tiger stripes". Specimen from Cagnes-sur-Mer, Alpes-Maritimes. Photo by Pierre Gros.

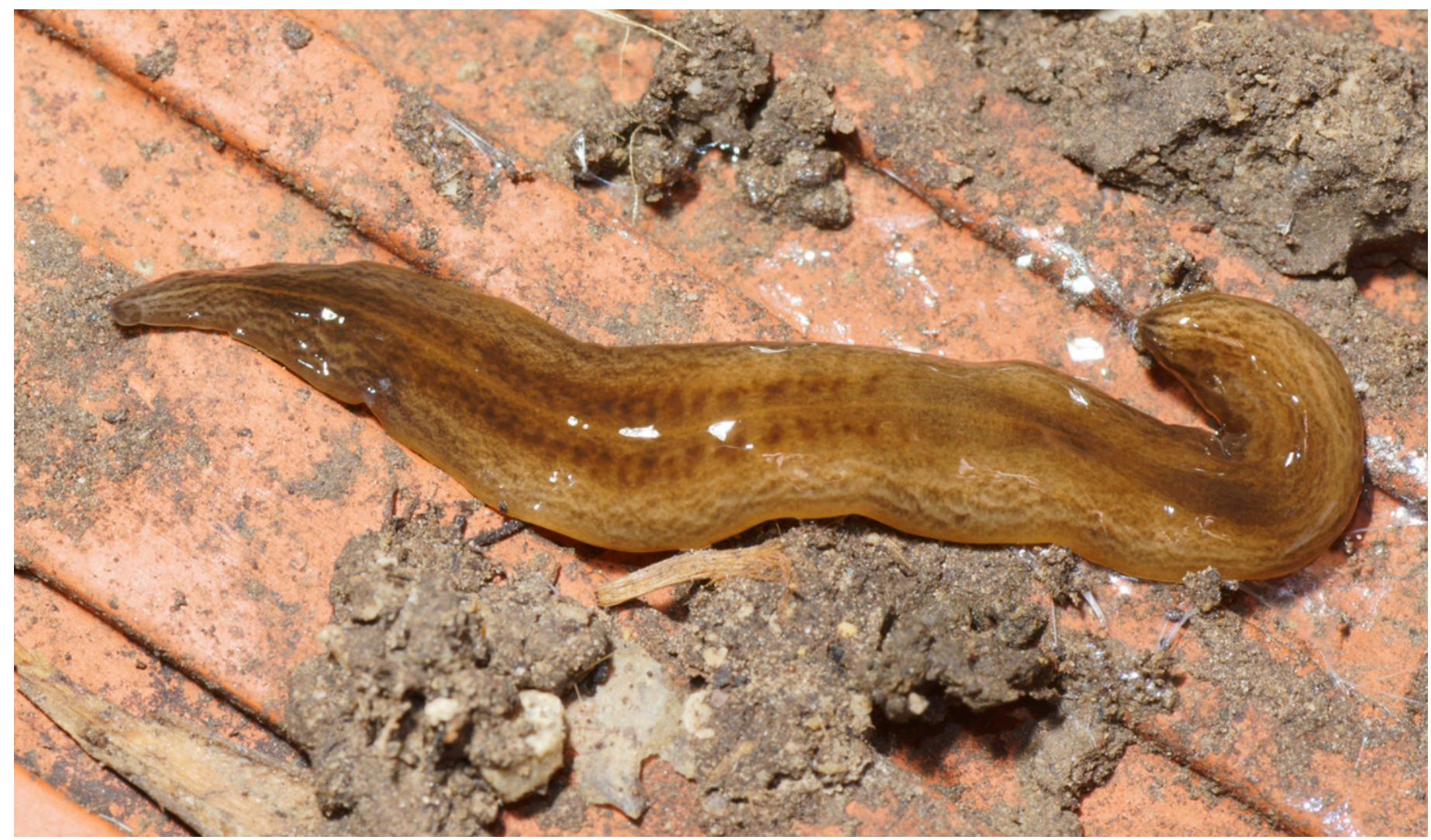




\section{Figure 4}

Obama nungara, specimen showing dorsal and ventral sides.

The ventral surface is pale. Specimen MNHN JL055 from Cagnes-sur-Mer, Alpes-Maritimes. Photo by Pierre Gros.

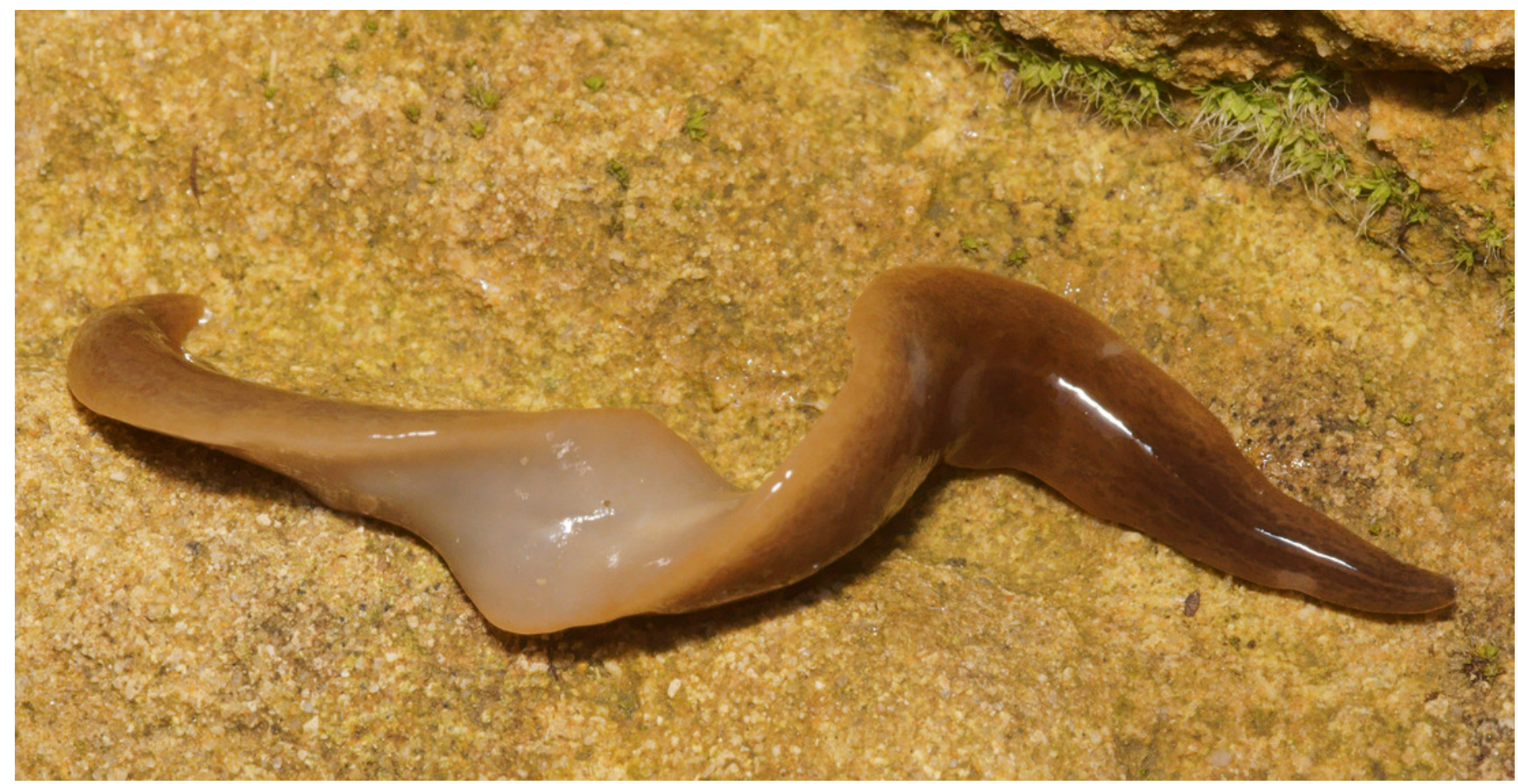




\section{Figure 5}

Obama nungara, anterior part showing eyes, right lateral view.

The "halo" effect of a clear zone around the eyes is present, though relatively inconspicuous in the pale form compared to the darker form. Specimen MNHN JL055 from Cagnes-sur-Mer, Alpes-Maritimes. Photo by Pierre Gros.

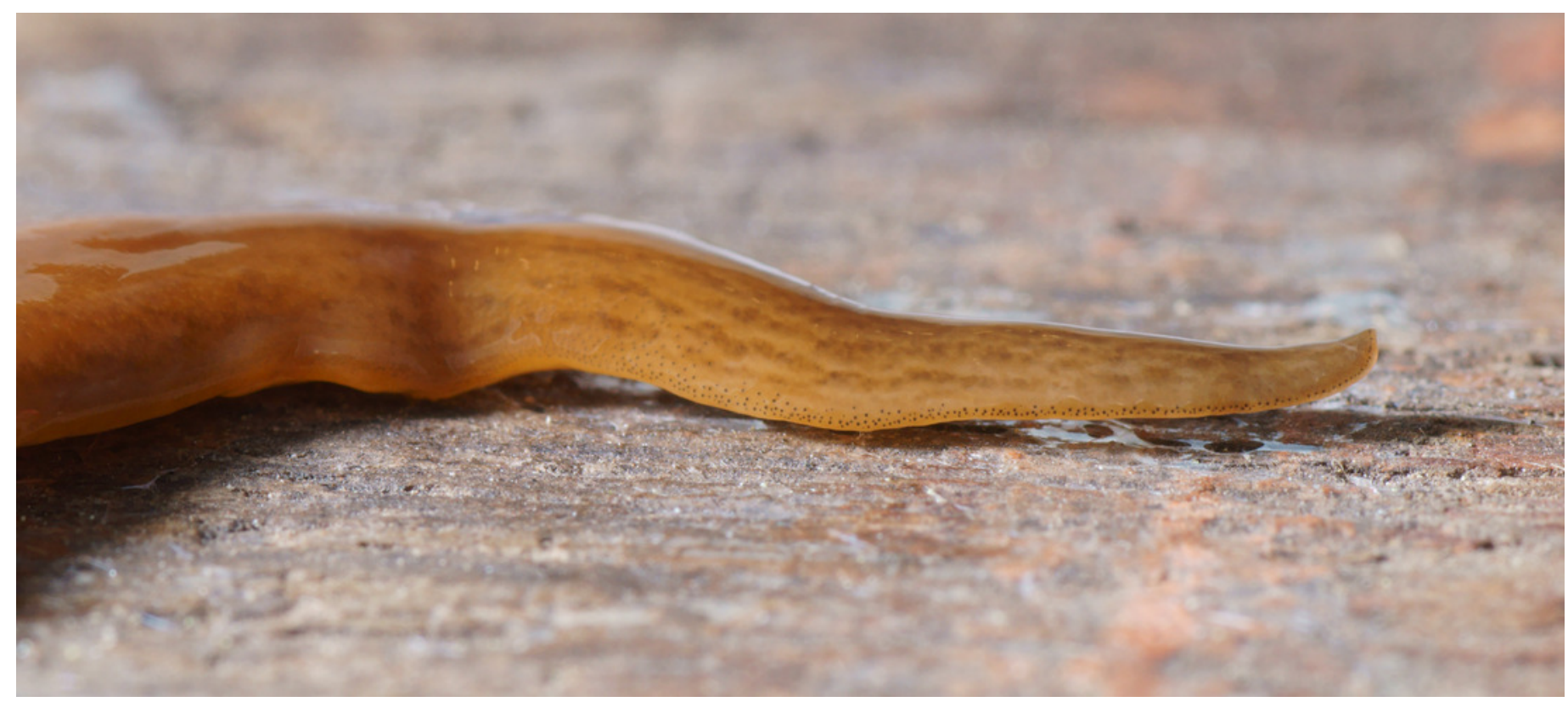


Figure 6

Obama nungara, dark form feeding on an earthworm.

The everted pharynx can be clearly seen partly enveloping the head of the earthworm (unidentified species). Specimen MNHN JL092 from Montauban, Tarn-et-Garonne. Photo by Pierre Gros. 


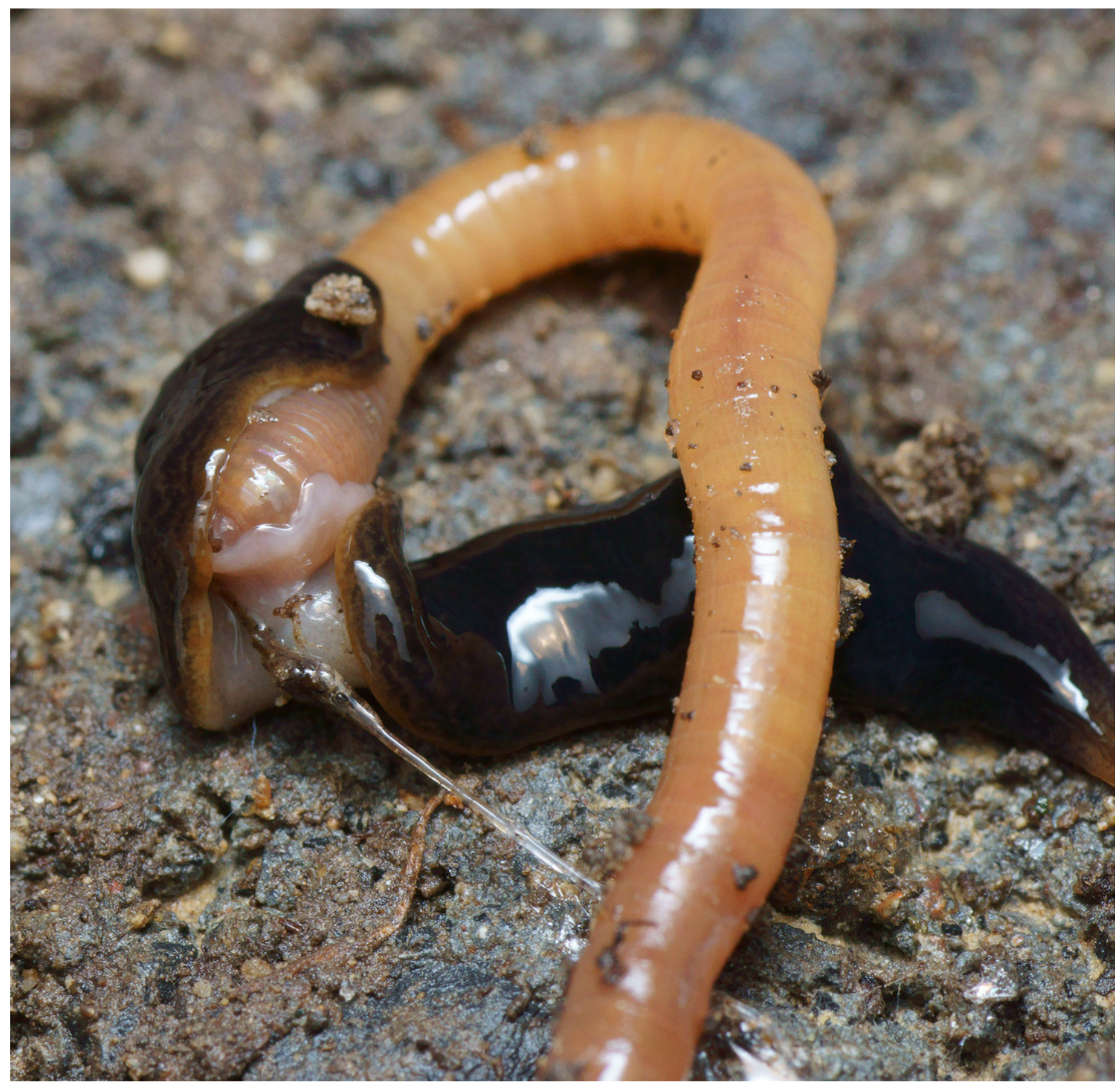




\section{Figure 7}

Obama nungara, dark form anterior part showing eyes.

Antero-lateral aspect showing "haloing" around the eyes. Specimen from Antibes, AlpesMaritimes. Photo by Pierre Gros. 
Figure 8

Obama nungara, adult specimen with cocoon.

The cocoon has been freshly laid and measures $4.8 \mathrm{~mm}$ in diameter; its colour is reddish. Photo by Pierre Gros.

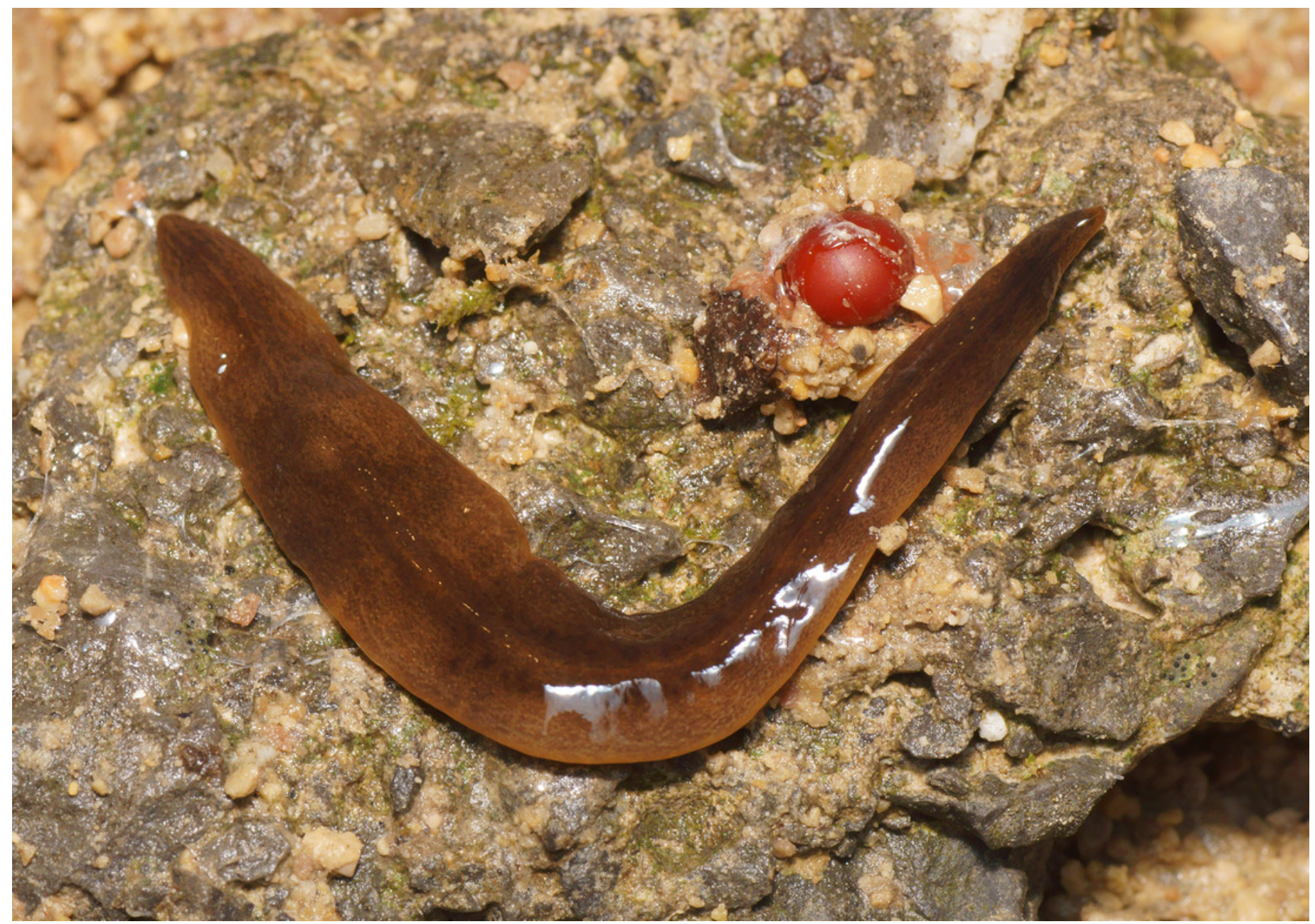


Figure 9

Obama nungara, adult specimen with cocoon.

The cocoon, 82 hours after being laid, measures $3.7-3.9$ mm diameter; its colour is now black. Cocoon laid by specimen MNHN JL92 from Montauban, Tarn-et-Garonne. Photo by Pierre Gros.

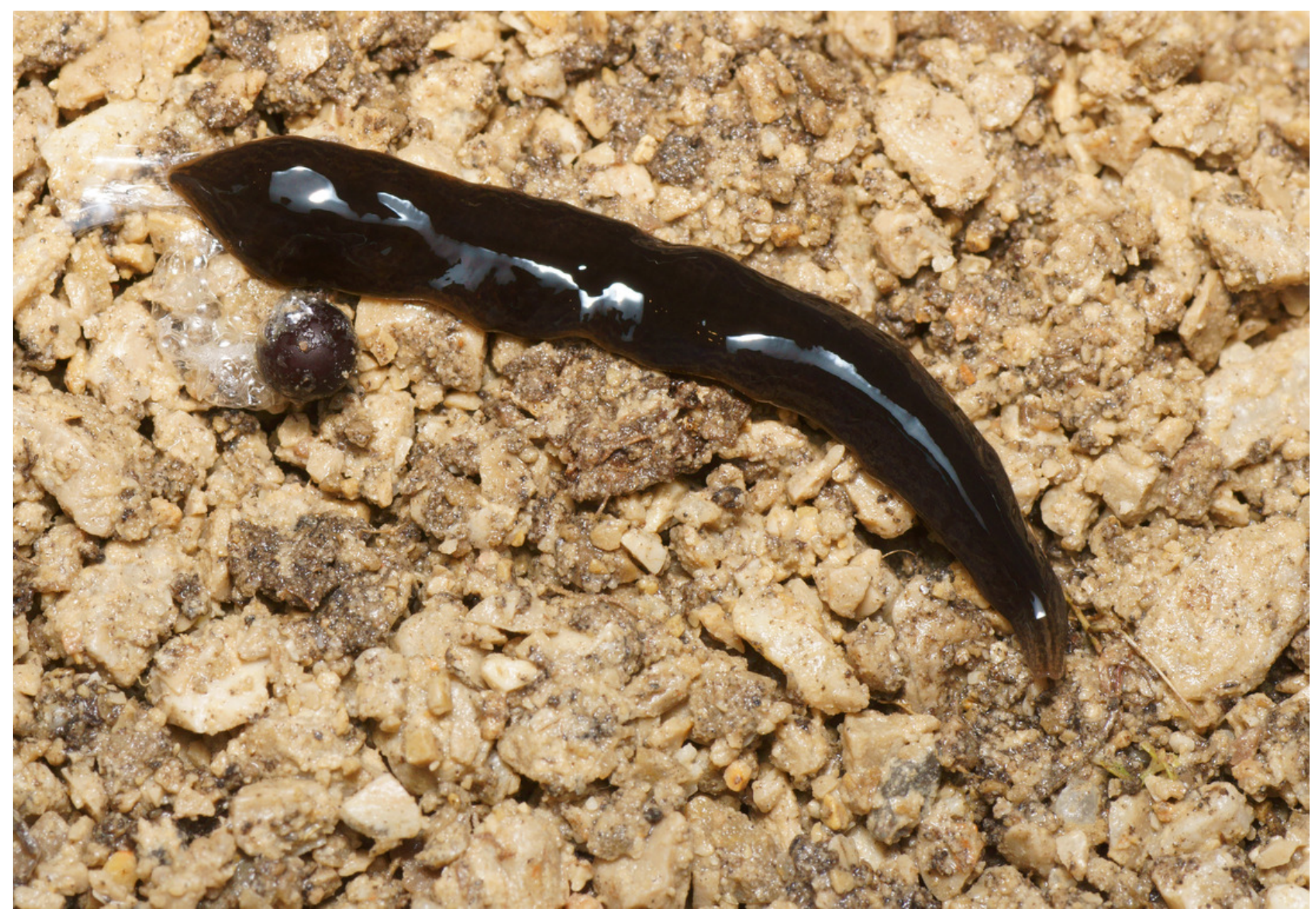




\section{Figure 10}

Obama nungara, juveniles.

The collapsed egg cocoon and the three juveniles that it contained. Cocoon laid by Specimen MNHN JL092 from Montauban, Tarn-et-Garonne. Photo by Pierre Gros.

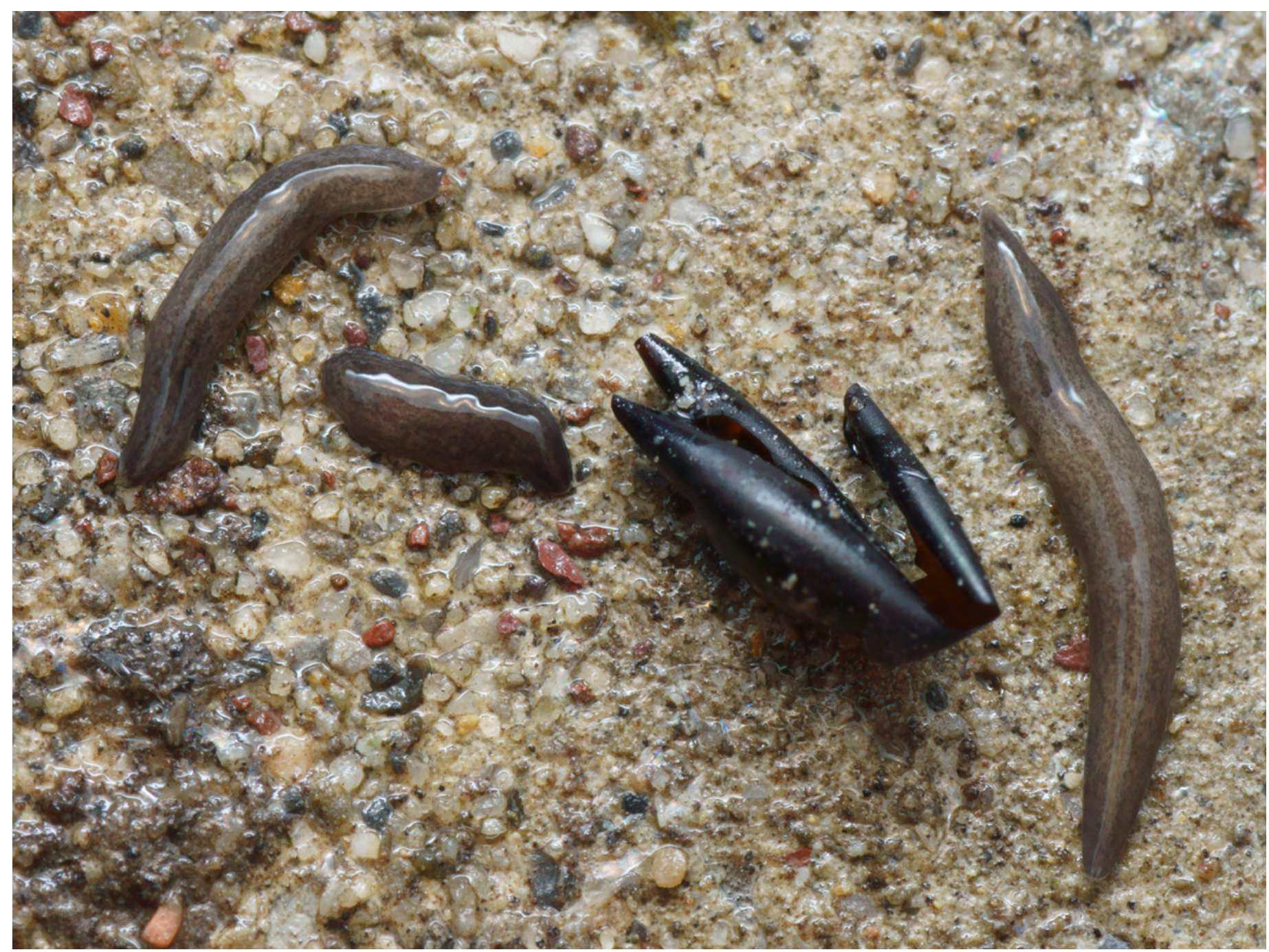




\section{Figure 11}

Obama nungara found in Paris in December 2013.

This single specimen was found in the Bois de Vincennes, Paris and the photograph was widely used by the French press. Specimen MNHN JL094, barcoded. Photograph by Xavier Japiot, CC-BY-SA-3.0.

https://commons.wikimedia.org/wiki/File:Planaria_Geoplanidae,_3_cm_(02).JPG

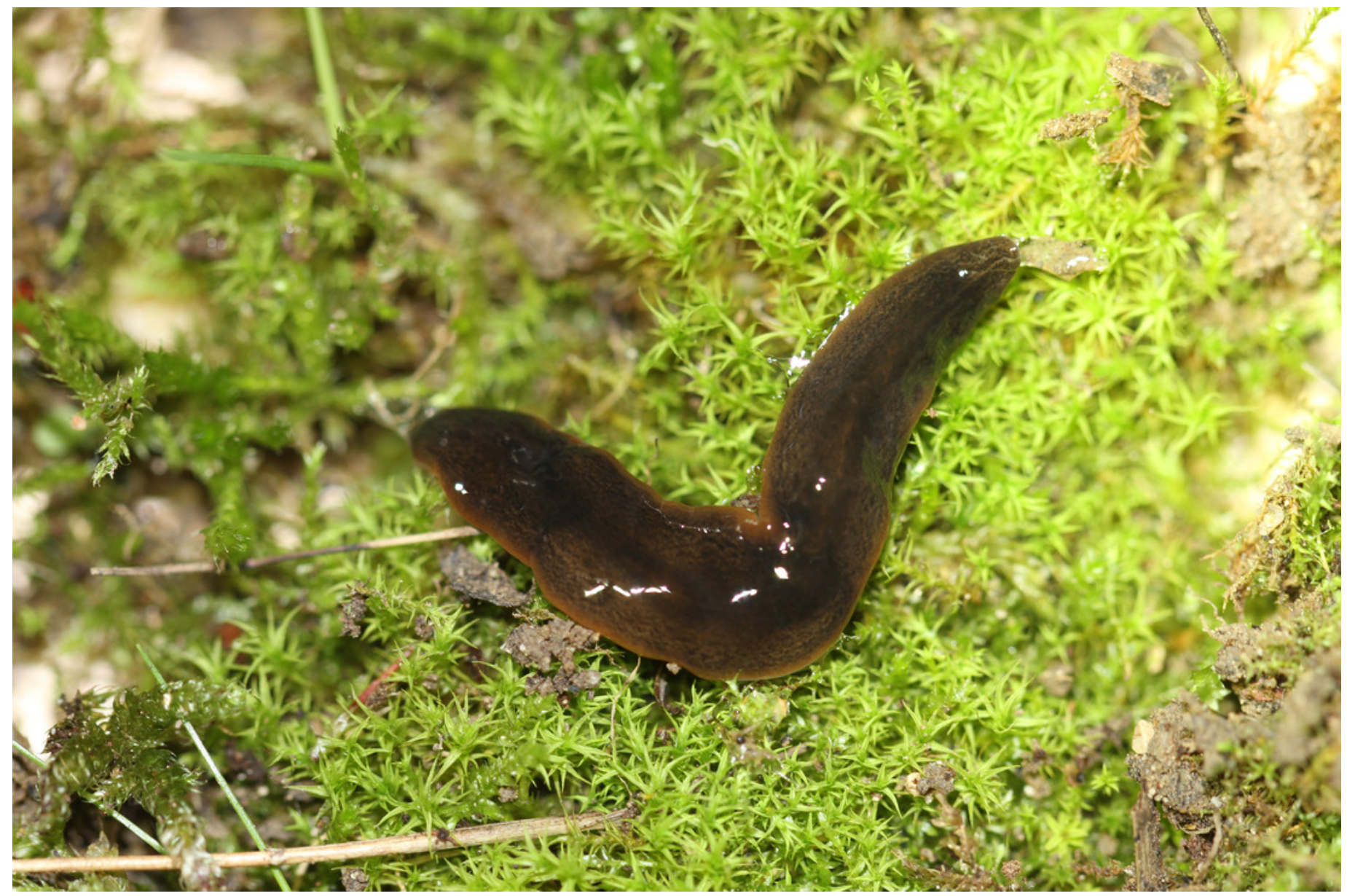




\section{Figure 12}

Large numbers of Obama nungara found in a garden.

A box filled with adult specimens collected by hand by a non-professional (Sylvain Petiet) in a single day in May 2015, in a small garden in Cabanac-et-Villagrains (Gironde). Photo by Sylvain Petiet.

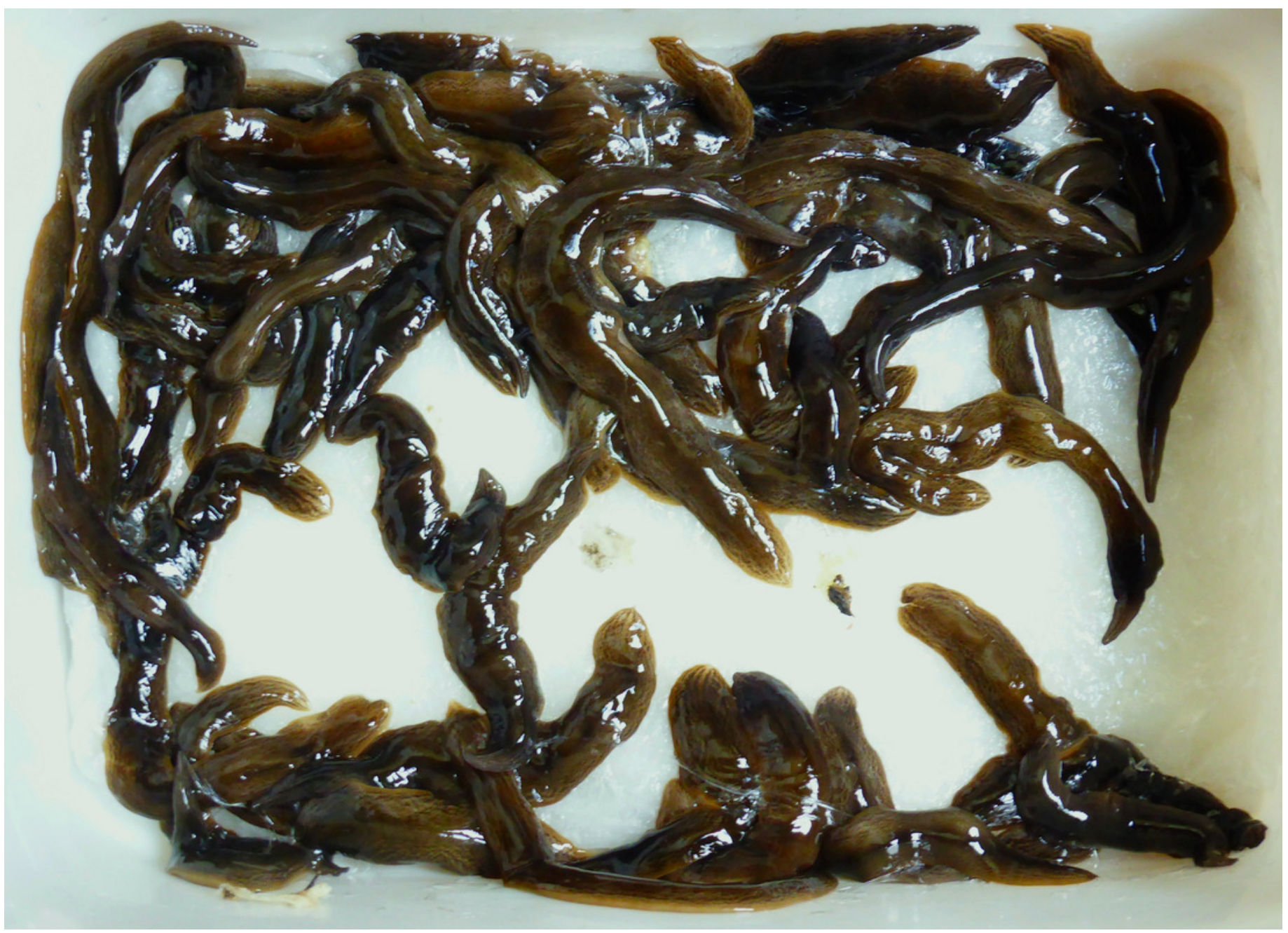




\section{Figure 13}

A sample of photographs of Obama nungara in gardens, received from nonprofessionals.

The photographs in $\mathrm{a}, \mathrm{e}$, and $\mathrm{h}$ are examples of the light brown colour; others are of the dark form. Scales in b, g: centimetres and millimetres; diameter of Euro 10 cent coin in h, i: 19.5 $\mathrm{mm}$; other images are unscaled. All authors have agreed to publication of their photographs under a CC-BY 4.0 licence. a, Cathy Constant-Elissagaray; b, Nicolas Armengaud; c, Julien Silvert; d, Frédéric Madre; e, Benjamin Klein; f, Françoise Bronnec; g, Louise Lejus; h, Fanny Tourraille; i, Christophe \& Amauray Amiand.

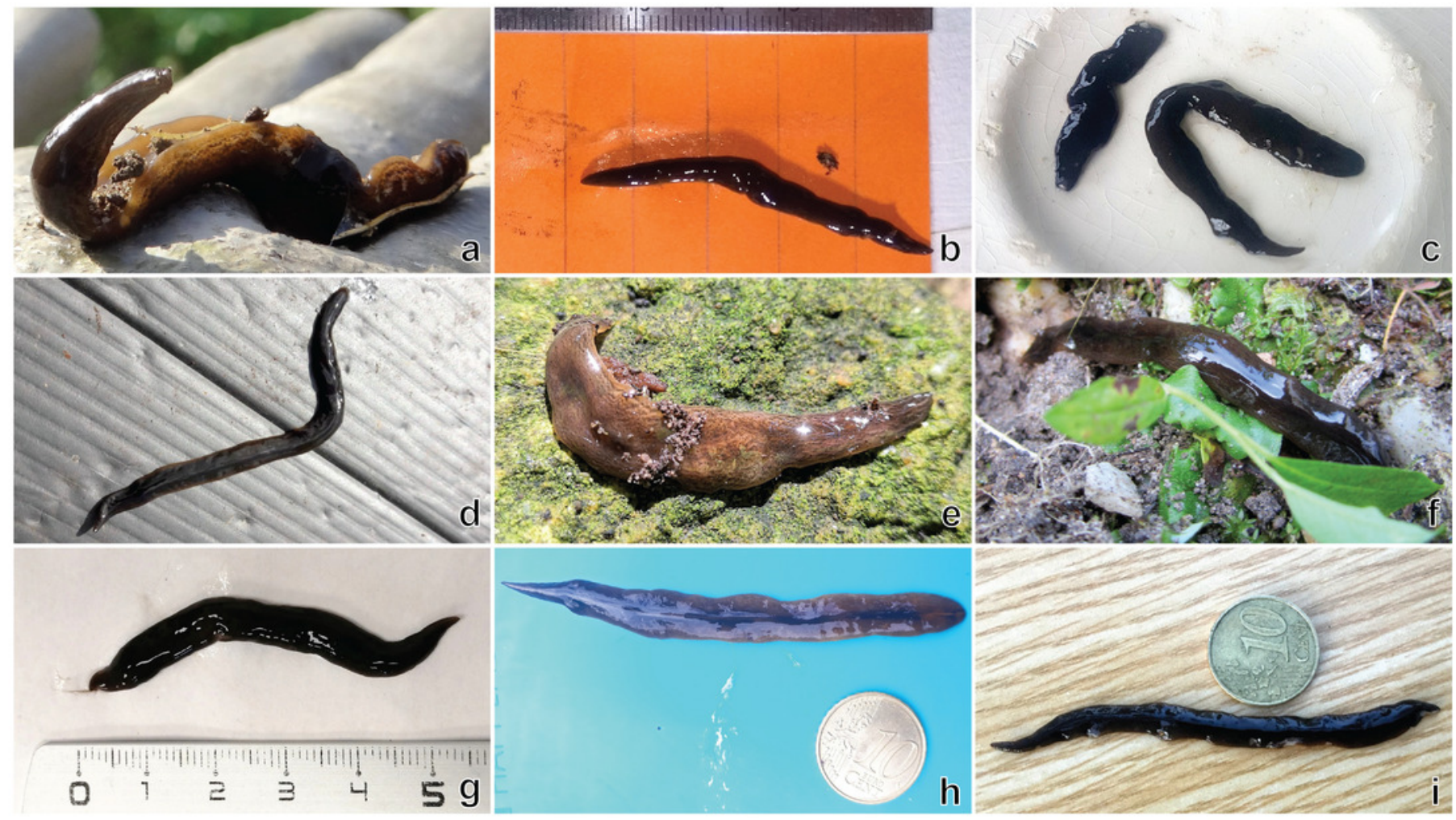




\section{Figure 14}

Map of records of Obama nungara in Metropolitan France in the period 2013-2018.

Each red dot is a record in the period 2013-2018. Some overlap between dots occurred. Note the concentration of records along the Atlantic and Mediterranean coasts. Mountainous parts (yellow on the map) were not invaded.

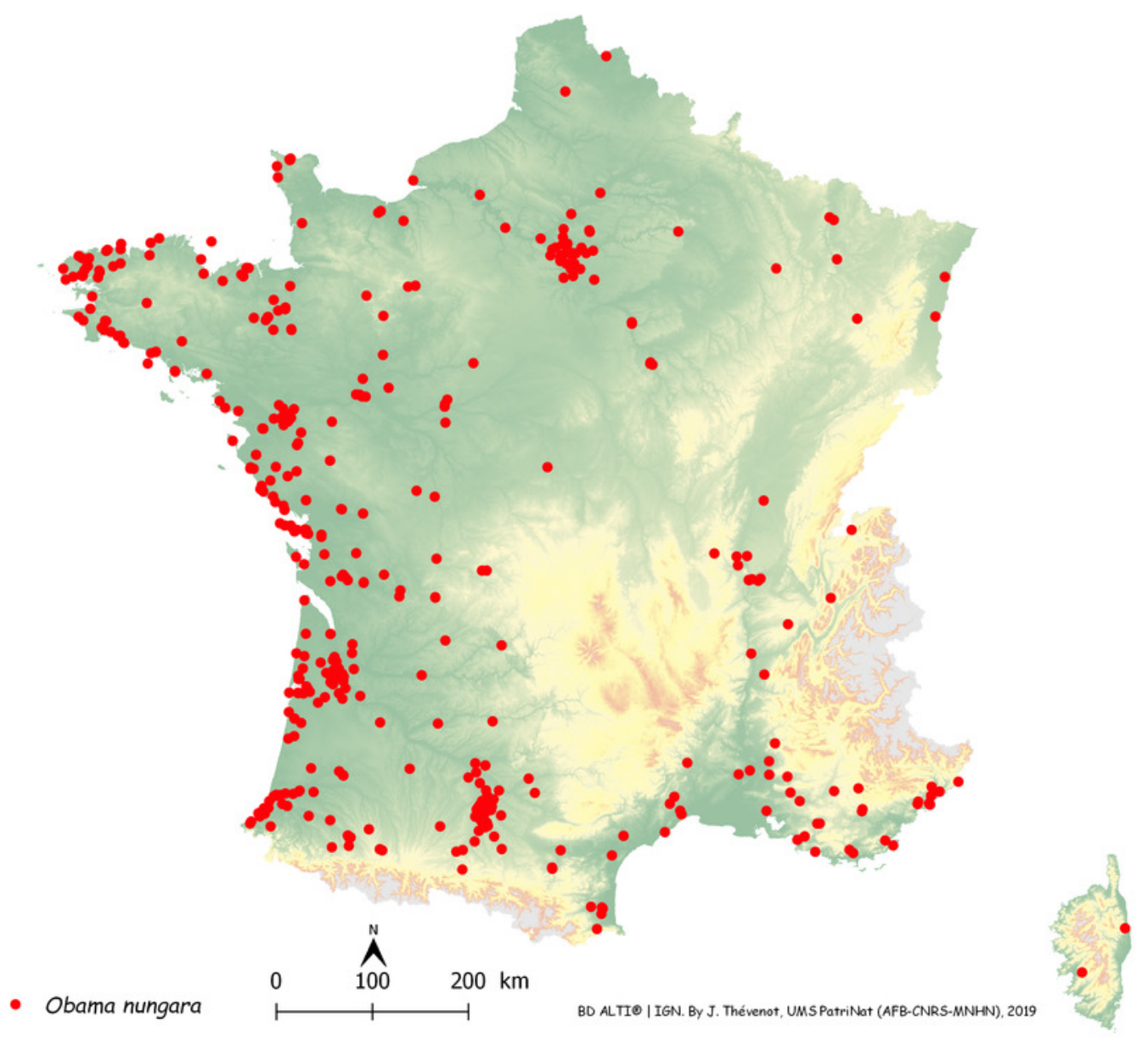




\section{Figure 15}

Map of records of Obama nungara in Metropolitan France in the period 2013-2018, shown as records in each Department.

Records are shown as number of records in each Department. The colour shows the intensity of the invasion. Note that all Departments along the Atlantic and Mediterranean coasts are heavily affected. The numbers (31 and 33) show two Departments (31, Haute-Garonne; 33, Gironde) that are mentioned in the discussion.

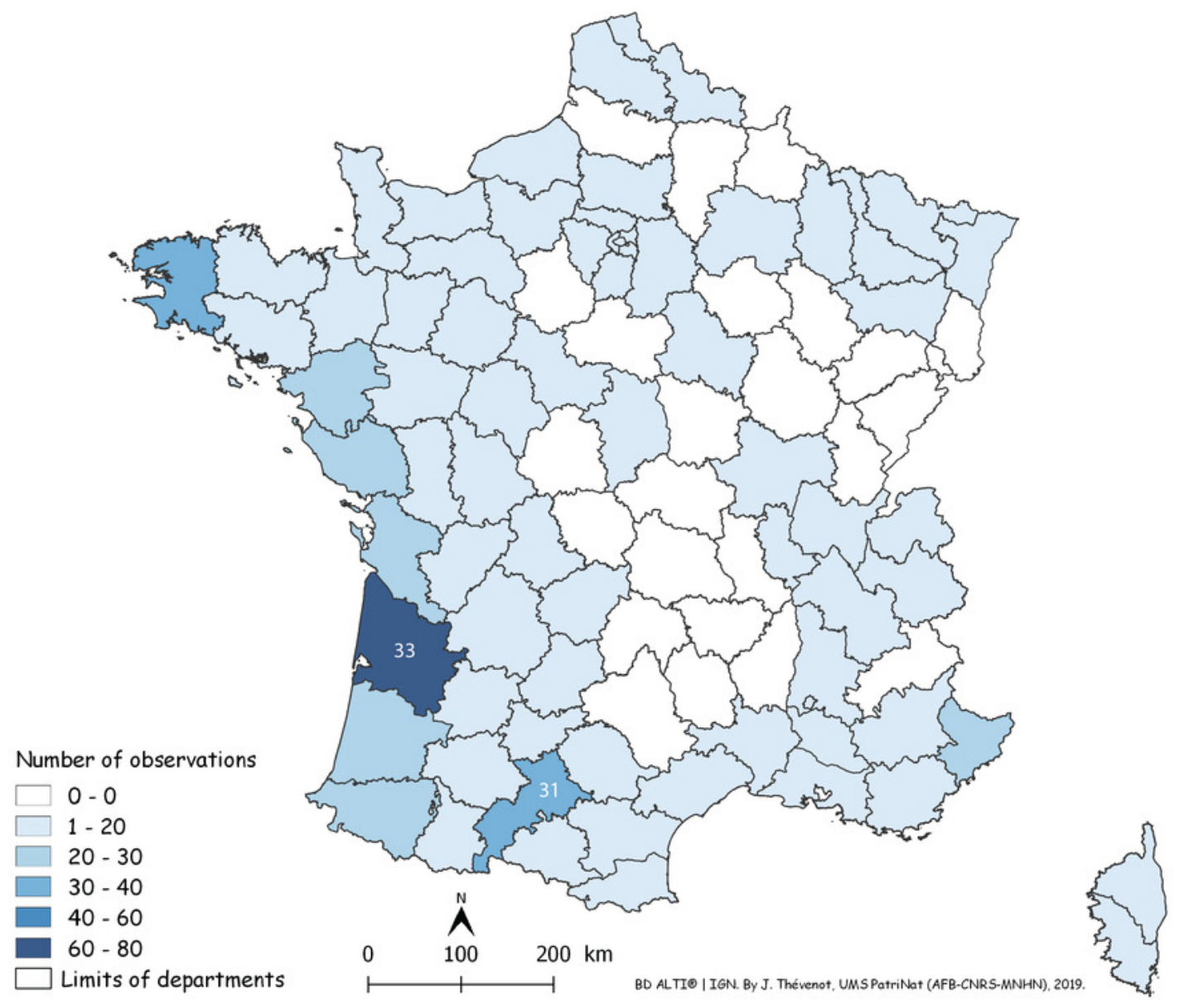


Figure 16

Altitude of localities in which Obama nungara was recorded in Metropolitan France.

More than half of the records were below $50 \mathrm{~m}$, and there were no records above $500 \mathrm{~m}$.

\section{Obama nungara: altitude of localities}

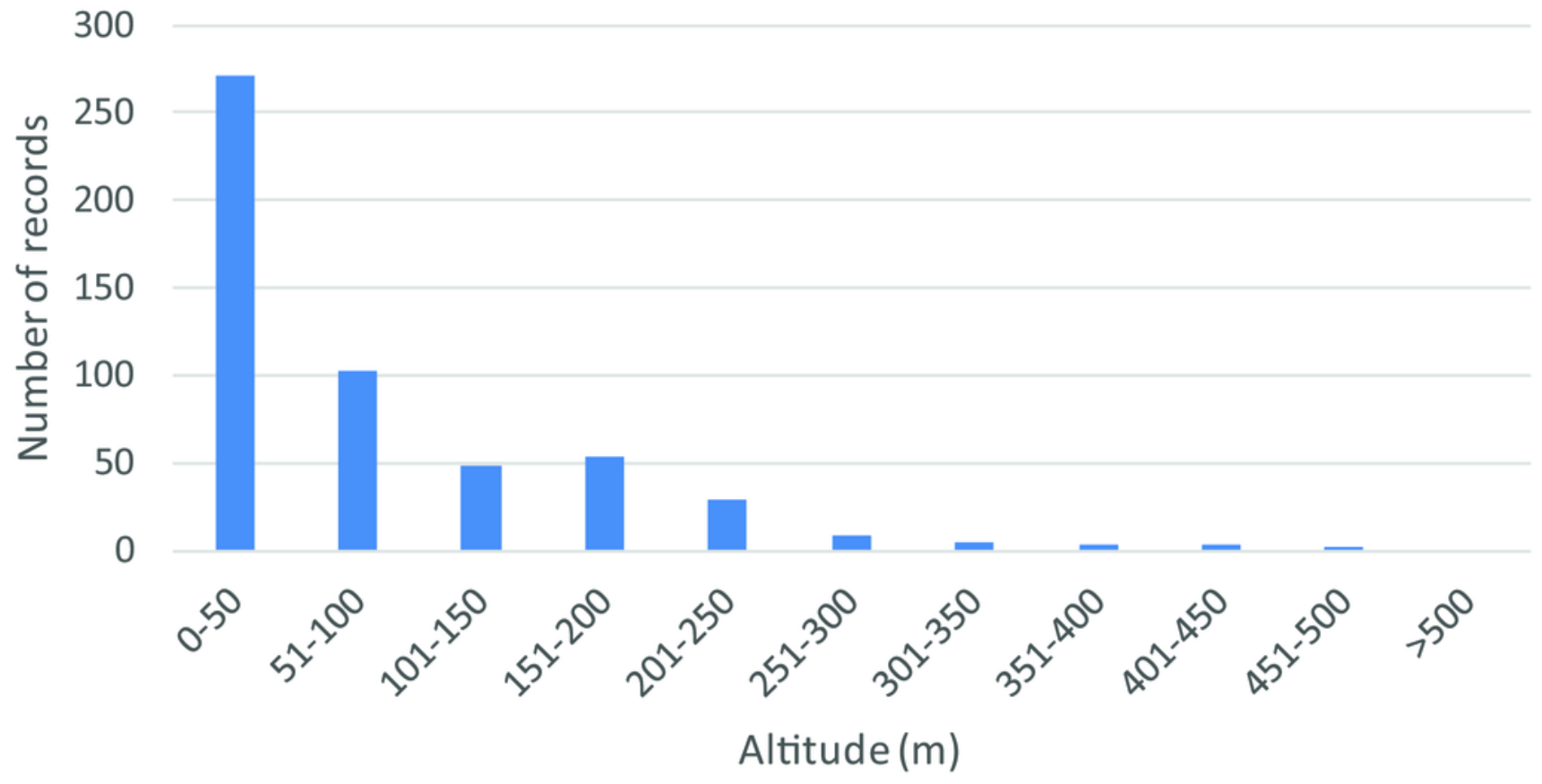




\section{Figure 17}

Maximum-likelihood tree of Obama nungara and close relatives.

The analyses involved 99 nucleotide sequences and there was a total of 255 positions in the final dataset. The matrix included a selection of available sequences of $O$. nungara and sequences of six other Obama species (noted with *), selected upon the absence of misreads. The percentage of trees in which the associated taxa clustered together is shown next to the branches (ML: Maximum Likelihood; NJ: Neighbour-Joining). Three clades are visible within O. nungara: "Argentina 1", "Argentina 2" and "Brazil", named after the country of origin of the South American sequences. Specimens from various localities in Europe, including all specimens from France, were included in the "Argentina 1" clade. A few specimens from Spain were included in the "Argentina 2" clade. No specimen from Europe was found in the "Brazil" clade. The geographic origin is indicated for each sequence; for France, the MNHN registration number of the specimen, the Department number and the administrative commune are indicated. The $O$. nungara clade includes many sequences that were deposited in GenBank under different names. 


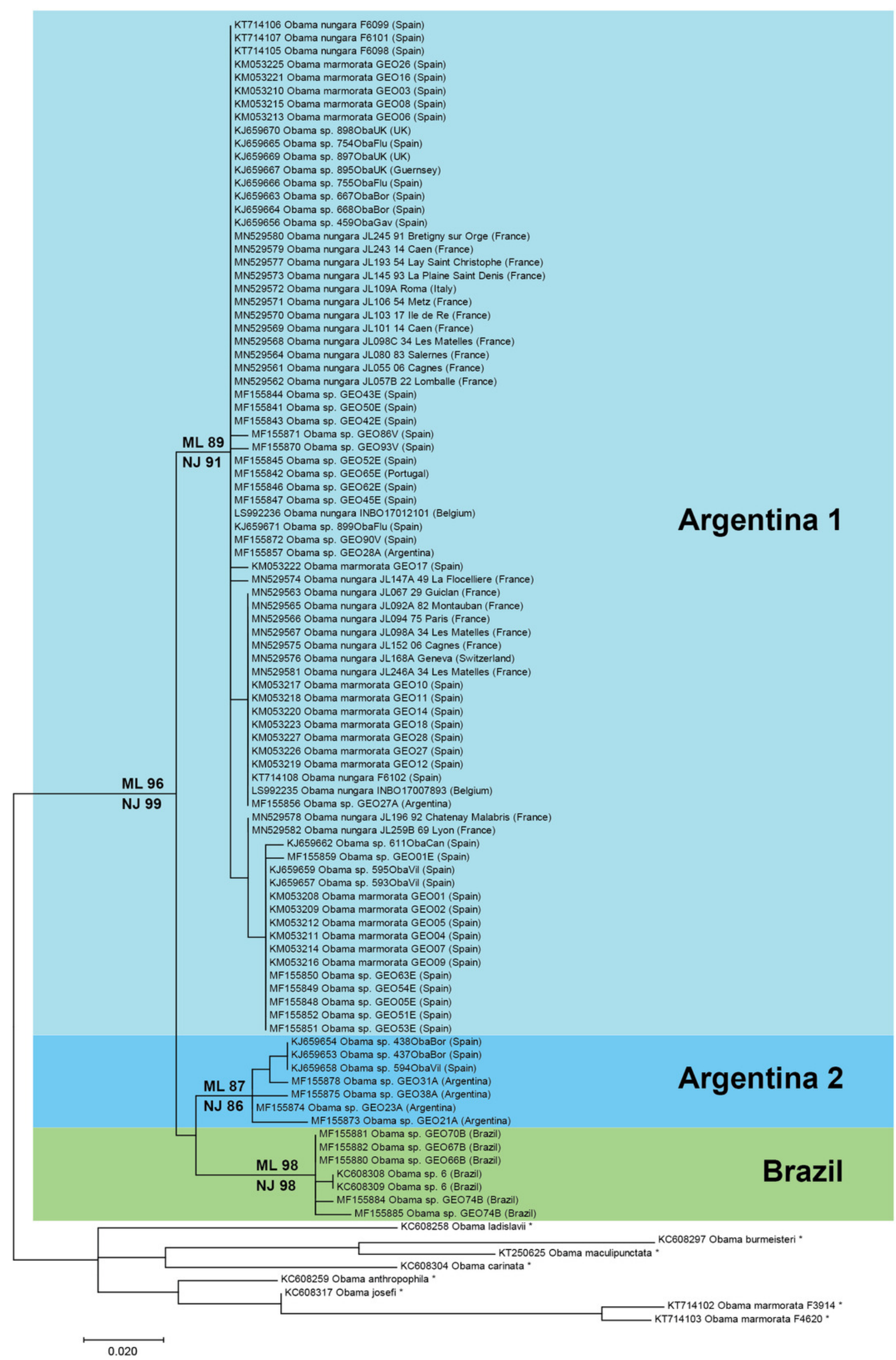




\section{Figure 18}

Simplified tree of the relationships within members of Obama nungara and with close species.

This simplified tree is drawn from the complete tree shown in Figure 17. There are three clades within $O$. nungara, representing three different populations within the species: "Argentina 1", "Argentina 2" and "Brazil", each with high support. Invasive specimens found in most countries in Europe (Spain, Portugal, France, the UK, Italy, and Switzerland) were included in the "Argentina 1" clade; however, a few specimens from Spain were included in the "Argentina 2" clade. No specimens from the "Brazil" clade were found in Europe. 


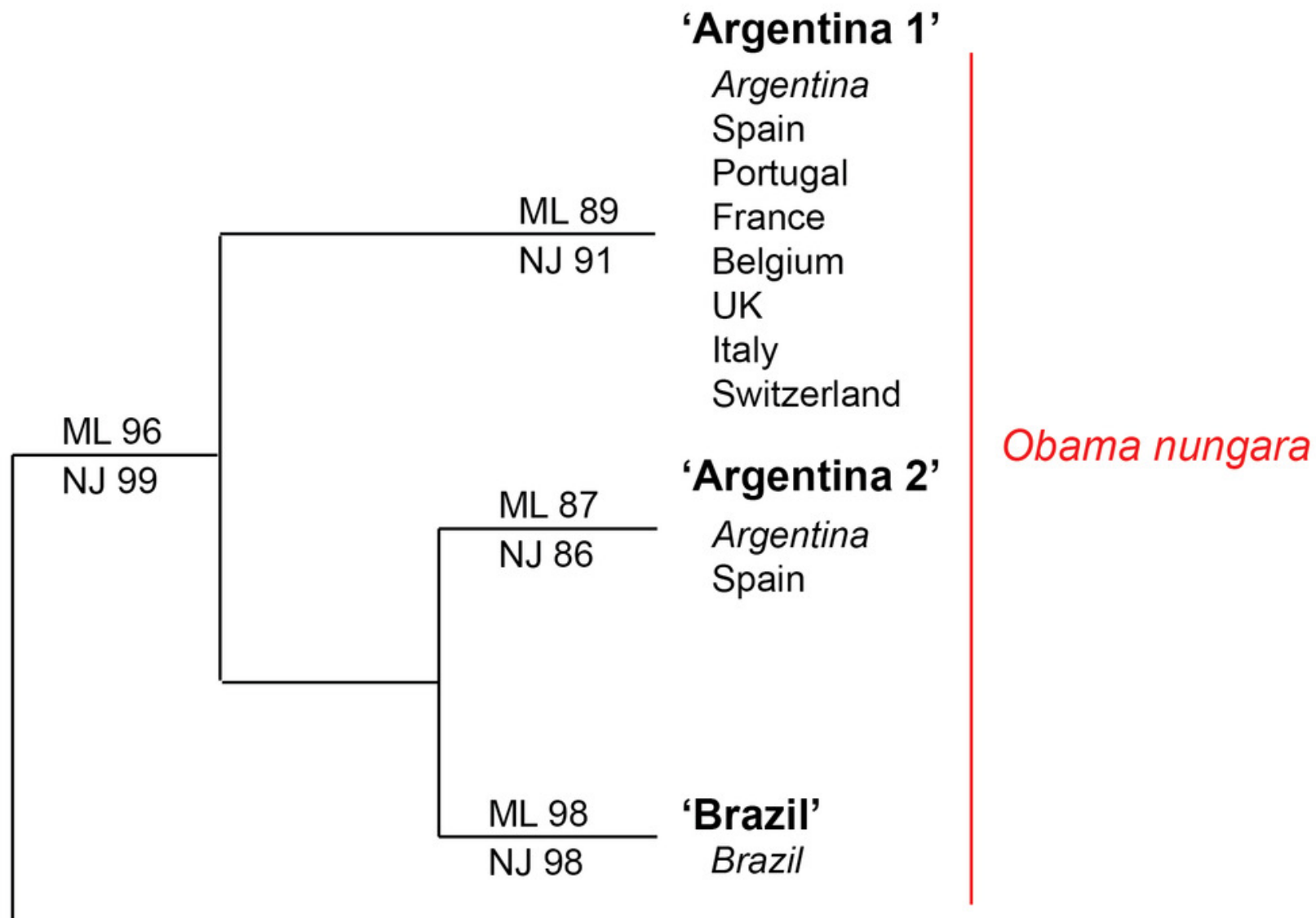

Obama spp. (other species) 


\section{Figure 19}

Network of relationships between specimens of Obama nungara from various localities.

Three groups are visible: "Argentina 1", "Argentina 2" and "Brazil". The main group, "Argentina 1", includes sequences from Argentina and all invaded countries in Europe. The group "Argentina 2" includes sequences from Argentina and a few from Spain, but no other country. The group "Brazil" includes only specimens from Brazil, none from Europe. Within the group "Argentina 1", three main haplotypes and 7 minor haplotypes are visible; two of the main haplotypes include both specimens from Argentina and most invaded European countries. 


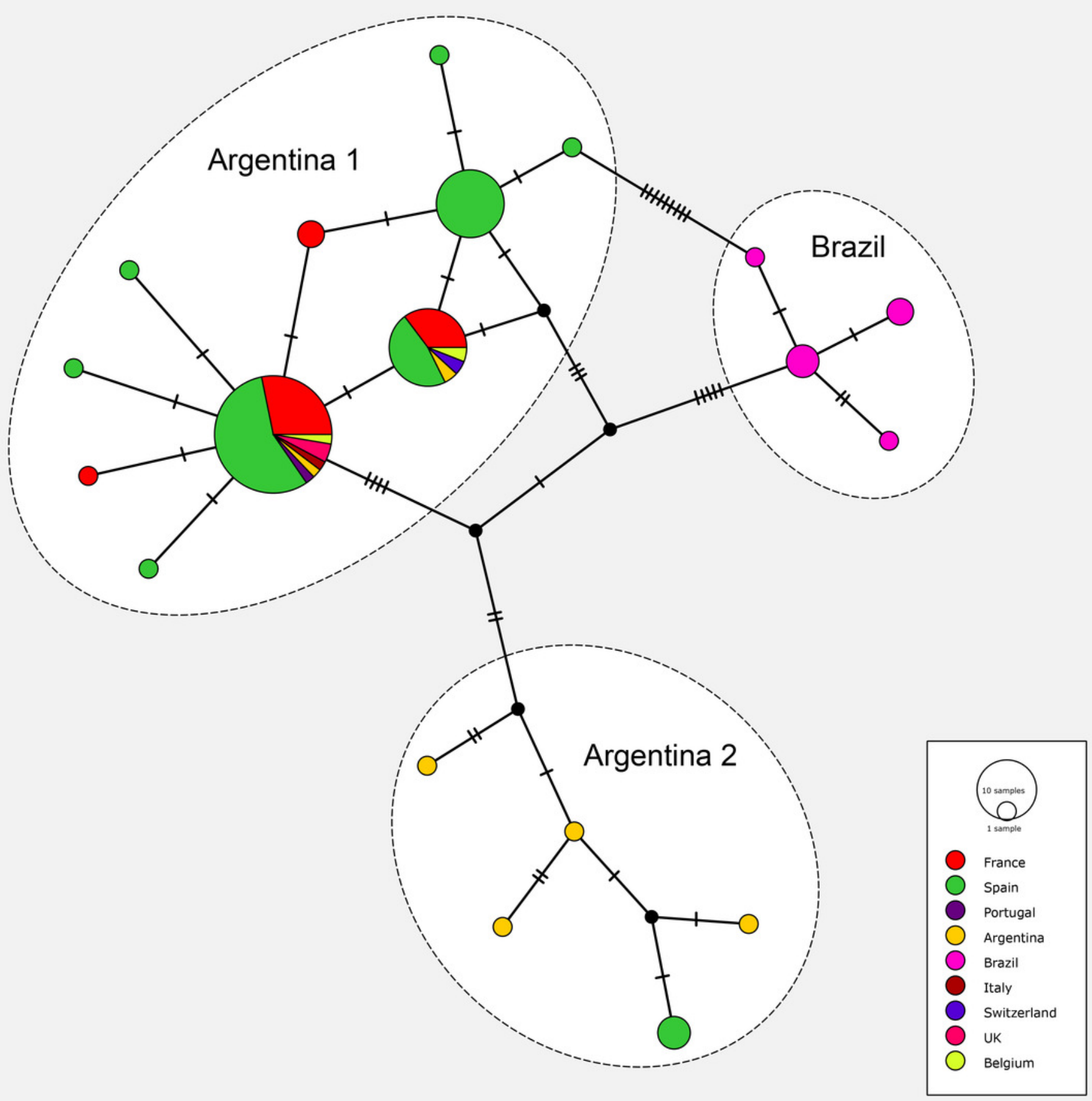


Figure 20

Number of reports of Obama nungara from 2013 to 2018 in France.

The reports obtained from citizen science are indicated for each year; 2013 includes only half of the year. There was a total of 530 verified records. See text for comments about the probable biases which explain the higher numbers of records in 2014 and 2018.

\section{Obama nungara: Reports - by year}

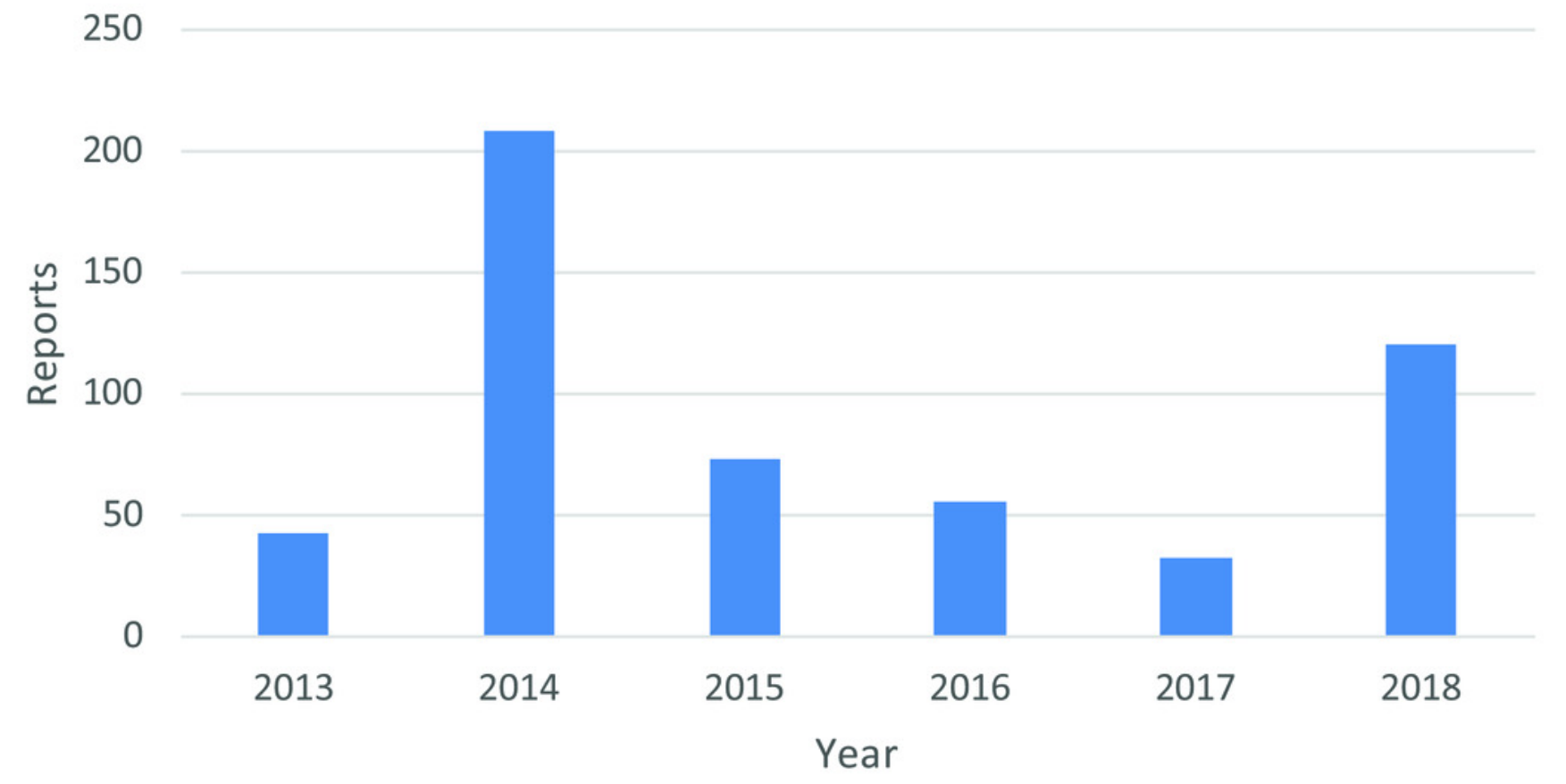


Figure 21

Monthly reports of Obama nungara from 2013 to 2018 in France.

All reports from 2013 to 2018 are here shown as monthly records. The highest number of records was obtained in May-June. See the discussion for a possible bias for these records.

Obama nungara: Reports per month (2013-2018) 100

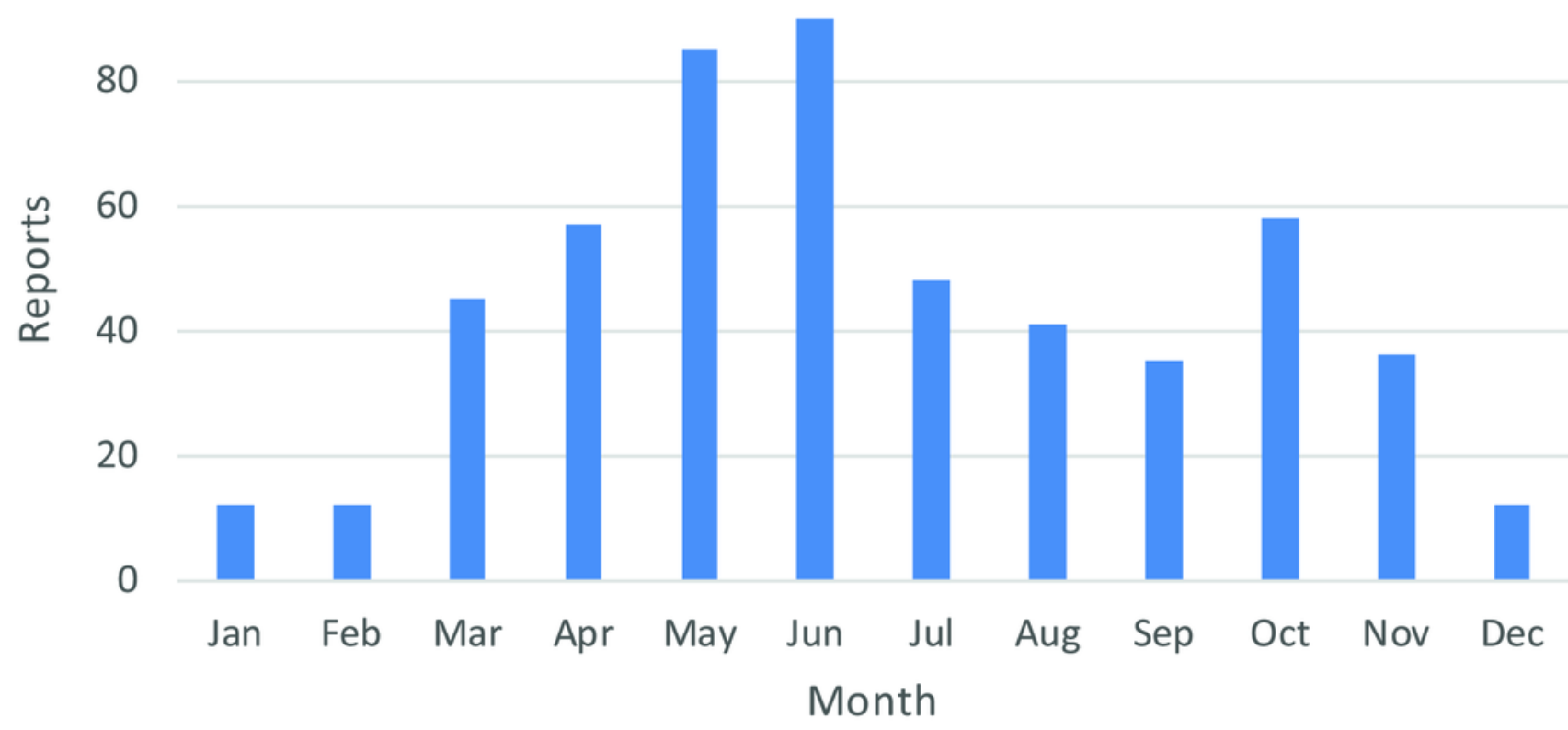




\section{Figure 22}

Reports of alien land planarians in 2018 in France (all species including Obama nungara), shown as weekly numbers.

The total number of records in 2018 was 262 . The peak in weeks 21-24 followed publication of our article in Peer], published 22 May 2018, and thus is not an indication of a higher number of animals in this period. See discussion for temporal biases in citizen science.

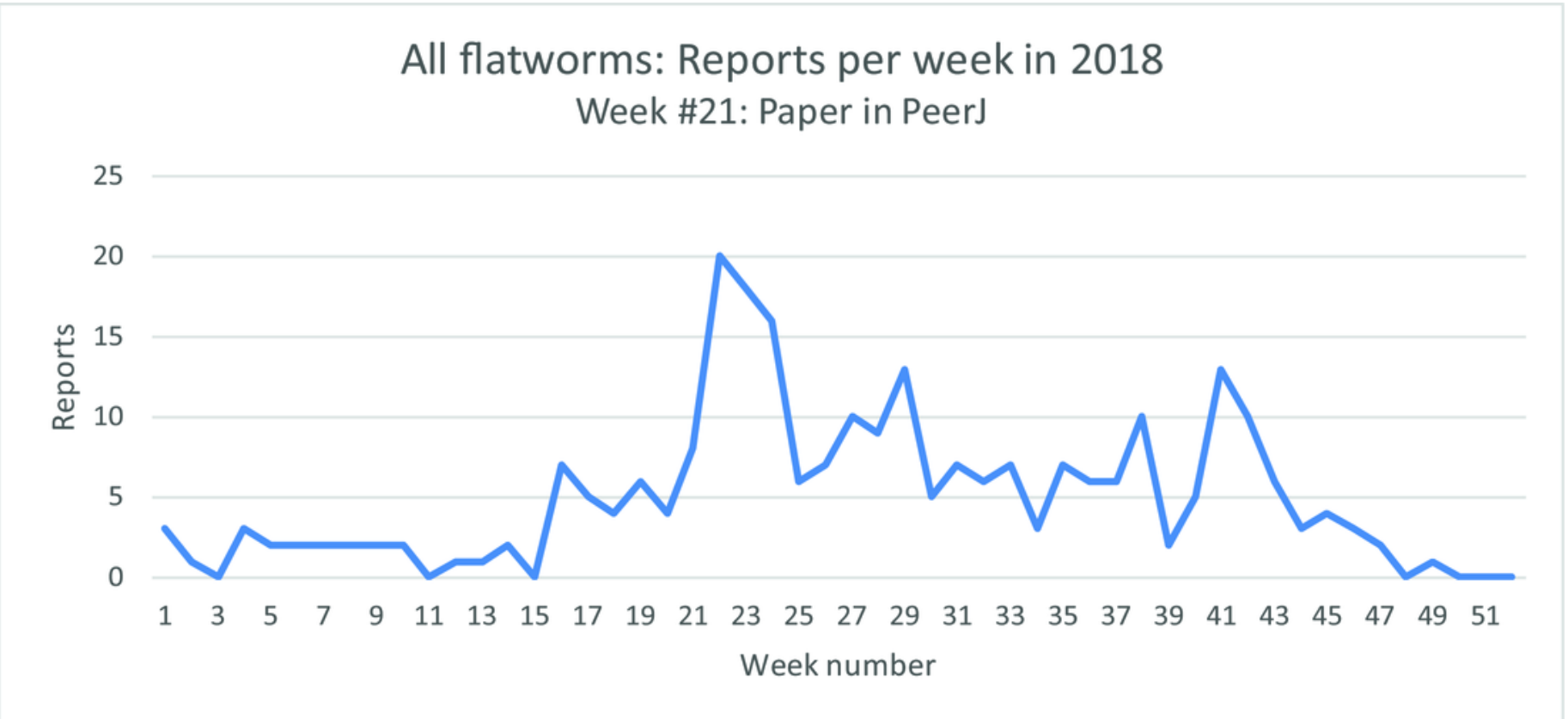




\section{Table $\mathbf{1}$ (on next page)}

Invasive land planarians found in Europe, authors of taxa and key references.

This table provides complete information about authors and taxa and combination, thus making the general text lighter. Sluys (2016) listed additional species with limited records and information: Artioposthia exulans Dendy, 1901, Australoplana sanguinea (Moseley, 1877), Dolichoplana striata Moseley, 1877, and Kontikia andersoni Jones, 1981. This Table updates a similar Table published in Justine et al. (2018). Synonyms are limited to binomials, various "sp." in GenBank not listed. 


\begin{tabular}{|c|c|c|c|}
\hline Taxon and authors & Synonyms & References for taxon & $\begin{array}{l}\text { Main references for } \\
\text { presence in Europe }\end{array}$ \\
\hline $\begin{array}{l}\text { Obama nungara Carbayo, Álvarez- } \\
\text { Presas, Jones \& Riutort, } 2016\end{array}$ & $\begin{array}{l}\text { Obama } \\
\text { marmorata pro } \\
\text { parte. }\end{array}$ & Carbayo et al. 2016 & $\begin{array}{l}\text { Carbayo et al. 2016; Lago- } \\
\text { Barcia et al. 2019; This } \\
\text { paper }\end{array}$ \\
\hline $\begin{array}{l}\text { Arthurdendyus triangulatus } \\
\text { (Dendy, 1896) Jones, } 1999\end{array}$ & $\begin{array}{l}\text { Artioposthia } \\
\text { triangulata }\end{array}$ & Dendy 1895; Jones 1999 & Boag et al. 1994 \\
\hline $\begin{array}{l}\text { Australopacifica atrata (Steel, } \\
\text { 1897) }\end{array}$ & $\begin{array}{l}\text { Geoplana } \\
\text { atrata; } \\
\text { Parakontikia } \\
\text { atrata; Kontikia } \\
\text { atrata }\end{array}$ & Steel 1897 & Jones 2019 \\
\hline Bipalium kewense Moseley, 1878 & & Moseley 1878 & Justine et al. 2018b \\
\hline $\begin{array}{l}\text { Caenoplana bicolor (Graff, 1899) } \\
\text { Winsor, } 1991\end{array}$ & $\begin{array}{l}\text { Geoplana } \\
\text { bicolor }\end{array}$ & $\begin{array}{l}\text { von Graff 1899; Winsor, } \\
1991\end{array}$ & Álvarez-Presas et al. 2014 \\
\hline $\begin{array}{l}\text { Caenoplana coerulea Moseley, } \\
1877\end{array}$ & & Moseley 1877 & $\begin{array}{l}\text { Álvarez-Presas et al. 2014; } \\
\text { Breugelmans et al. } 2012\end{array}$ \\
\hline Diversibipalium "black" & & Justine et al. 2018b & Justine et al. 2018b \\
\hline $\begin{array}{l}\text { Diversibipalium multilineatum } \\
\text { (Makino \& Shirasawa, 1983) } \\
\text { Kubota \& Kawakatsu, } 2010\end{array}$ & $\begin{array}{l}\text { Bipalium } \\
\text { multilineatum }\end{array}$ & $\begin{array}{l}\text { Makino \& Shirasawa } \\
\text { 1983; Kubota \& } \\
\text { Kawakatsu } 2010\end{array}$ & $\begin{array}{l}\text { Justine et al. 2018b; Mazza } \\
\text { et al. } 2016\end{array}$ \\
\hline $\begin{array}{l}\text { Marionfyfea adventor Jones \& } \\
\text { Sluys, } 2016\end{array}$ & & Jones \& Sluys 2016 & Jones \& Sluys 2016 \\
\hline $\begin{array}{l}\text { Parakontikia ventrolineata (Dendy, } \\
\text { 1892) Winsor, } 1991\end{array}$ & $\begin{array}{l}\text { Kontikia } \\
\text { ventrolineata }\end{array}$ & Dendy 1892; Winsor 1991 & Álvarez-Presas et al. 2014 \\
\hline $\begin{array}{l}\text { Platydemus manokwari de } \\
\text { Beauchamp, } 1963\end{array}$ & & de Beauchamp 1962 & Justine et al. $2014 b$ \\
\hline
\end{tabular}




\section{Table 2 (on next page)}

Records of Obama nungara in Europe.

The year is indicated as the date of the first record or first specimen mentioned in the reference; actual presence of the species may predate the year mentioned. 


\begin{tabular}{|c|c|c|}
\hline Country or territory & Year & Reference \\
\hline Guernsey Island & 2008 & Carbayo et al. 2016 \\
\hline Mainland United Kingdom & 2009 & Carbayo et al. 2016 \\
\hline Spain & 2010 & Carbayo et al. 2016 \\
\hline Portugal & $\mathrm{N} / \mathrm{A}$ & Lago-Barcia et al. 2019 \\
\hline $\begin{array}{l}\text { Metropolitan France (excluding Corsica } \\
\text { Island) }\end{array}$ & 2013 & Justine et al. 2014a; this paper \\
\hline Corsica & 2013 & This paper \\
\hline Italy & 2012 & Carbayo et al. 2016; this paper \\
\hline Switzerland & 2014 & This paper \\
\hline Ireland & 2009 & $\begin{array}{l}\text { Hugh Jones, personal } \\
\text { communication, 2019; collection and } \\
\text { identification: R. Anderson. }\end{array}$ \\
\hline Madeira Island & 2018 & $\begin{array}{l}\text { Hugh Jones, personal } \\
\text { communication, } 2019\end{array}$ \\
\hline The Netherlands & 2016 & Aldred 2016 \\
\hline $\begin{array}{l}\text { In the UK, in a pot plant allegedly } \\
\text { "imported from the Netherlands" }\end{array}$ & & \\
\hline Belgium & 2017 & Soors et al. 2019 \\
\hline
\end{tabular}




\section{Table 3(on next page)}

Specimens of $O$. nungara used for molecular analysis.

All specimens were adults, except JL067, received as cocoons. All records are from France, except one record from Italy and one from Switzerland. 


\begin{tabular}{|c|c|c|c|c|c|c|}
\hline GenBank & MNHN & Date & Locality & $\begin{array}{l}\text { Department or } \\
\text { Country }\end{array}$ & COI & Collector \\
\hline MN529561 & JL055 & $30 / 04 / 2013$ & Cagnes-sur-Mer & Alpes-Maritimes & Long & Pierre Gros \\
\hline MN529562 & JL057B & $17 / 05 / 2013$ & Lamballe & Côtes-d'Armor & Long & Benoît L'Hotellier \\
\hline MN529563 & JL067 & $10 / 10 / 2013$ & Guiclan & Finistère & Long & Madame Stephan (Cocoon) \\
\hline MN529564 & JL080 & $19 / 08 / 2013$ & Salernes & Var & Long & Daniel Juif \\
\hline MN529565 & JL092A & $26 / 11 / 2013$ & Montauban & Tarn-et-Garonne & Long & Céline Tan \\
\hline MN529566 & JL094 & $04 / 12 / 2013$ & Paris & Paris & Long & Xavier Japiot (VILLE DE PARIS) \\
\hline MN529567 & JL098A & $27 / 03 / 2014$ & Les Matelles & Hérault & Short & Benoit Jaillard (INRA) \\
\hline MN529568 & JL098C & $27 / 03 / 2014$ & Les Matelles & Hérault & Short & Benoit Jaillard (INRA) \\
\hline MN529569 & JL101 & $02 / 04 / 2014$ & Hérouville-Saint-Clair & Calvados & Short & Daniel Loisel (FREDON) \\
\hline MN529570 & JL103 & $21 / 06 / 2014$ & Ile de Ré & Charente-Maritime & Short & Félix Bécheau \\
\hline MN529571 & JL106 & $02 / 04 / 2014$ & Metz & Moselle & Long & Charlie Sommer (FREDON) \\
\hline MN529572 & JL109A & $29 / 03 / 2014$ & Rome & Italy & Long & Di Pompeo et al. \\
\hline MN529573 & JL145 & $06 / 05 / 2014$ & La Plaine Saint Denis & Seine-Saint-Denis & Short & Dhyma Gomez \\
\hline MN529574 & JL147A & $16 / 05 / 2014$ & La Flocellière (Sèvremont) & Vendée & Short & Jocelyn Foucher \\
\hline MN529575 & JL152 & $24 / 06 / 2014$ & Cagnes-sur-Mer & Alpes-Maritimes & Long & Pierre Gros \\
\hline MN529576 & JL168A & $14 / 08 / 2014$ & Geneva & Switzerland & Long & Corinne Jasquelin (DGNP, Genève) \\
\hline MN529577 & JL193 & $19 / 10 / 2014$ & Lay-Saint-Christophe & Meurthe-et-Moselle & Long & Emeline Notte (AREXHOR) \\
\hline MN529578 & JL196 & $07 / 11 / 2014$ & Châtenay-Malabry & Hauts-de-Seine & Long & Thibault Garnier Boudier (DEPT) \\
\hline MN529579 & JL243 & $26 / 03 / 2015$ & Caen & Calvados & Long & Arnaud Pudepiece (FREDON) \\
\hline MN529580 & JL245 & $21 / 03 / 2015$ & Brétigny-sur-Orge & Essonne & Long & Nicolas Puillandre (MNHN) \\
\hline MN529581 & JL246A & $07 / 04 / 2015$ & Les Matelles & Hérault & Long & Benoit Jaillard (INRA) and students \\
\hline MN529582 & JL259B & $26 / 05 / 2015$ & Lyon & Rhône & Short & Cloé Laurent (VILLE DE LYON) \\
\hline
\end{tabular}




\section{Table 4 (on next page)}

Number of specimens of Obama nungara in a garden.

The specimens were collected and destroyed every day by a non-professional in a $175 \mathrm{~m}^{2}$ garden in Metropolitan France, from November 2015 to May 2016. May 2016, only first 20 days. Data by Michel Hir. 


\begin{tabular}{lrrrrrrrr}
\hline & November & December & January & February & March & April & May (20 days) & Total \\
Total & 477 & 414 & 110 & 107 & 52 & 232 & 50 & 1442 \\
Mean/day & 19 & 17 & 6 & 6 & 4 & 11 & 8 & 10 \\
\hline
\end{tabular}

1 


\section{Table 5 (on next page)}

Genetic distances between and inside clades of Obama nungara.

Results are given as percentages and mean distances, according to several methods (Tamura-3, Kimura-2 parameter, p-distance, Maximum Composite Likelihood). Differences between the various methods were minor, and the three clades of $O$. nungara were well separated between them and from the outgroup and had minor intragroup variation (in italics). The outgroup was composed of 7 other species of Obama. 


\begin{tabular}{|c|c|c|c|}
\hline \multicolumn{4}{|l|}{ Method } \\
\hline \multicolumn{4}{|l|}{ Tamura-3 } \\
\hline & Argentina 1 & Argentina 2 & Brazil \\
\hline Within group & 0.40 & 1.15 & 0.53 \\
\hline Argentina 2 & 3.89 & & \\
\hline Brazil & 4.32 & 4.78 & \\
\hline Outgroup & 10.69 & 11.21 & 11.49 \\
\hline \multicolumn{4}{|l|}{$p$-distance } \\
\hline & Argentina 1 & Argentina 2 & Brazil \\
\hline Within group & 0.39 & 1.12 & 0.52 \\
\hline Argentina 2 & 3.62 & & \\
\hline Brazil & 4.07 & 4.47 & \\
\hline Outgroup & 9.25 & 9.64 & 9.82 \\
\hline \multicolumn{4}{|l|}{ Kimura-2 } \\
\hline & Argentina 1 & Argentina 2 & Brazil \\
\hline Within group & 0.40 & 1.15 & 0.53 \\
\hline Argentina 2 & 3.84 & & \\
\hline Brazil & 4.31 & 4.76 & \\
\hline Outgroup & 10.60 & 11.11 & 11.39 \\
\hline \multicolumn{4}{|c|}{ Maximum Composite Likelihood } \\
\hline & Argentina 1 & Argentina 2 & Brazil \\
\hline Within group & 0.40 & 1.18 & 0.54 \\
\hline Argentina 2 & 4.11 & & \\
\hline Brazil & 4.89 & 5.39 & \\
\hline Outgroup & 15.76 & 16.89 & 17.61 \\
\hline
\end{tabular}

1 